\title{
Chapter 3: The origin(s) of the medieval calendar tradition in the Latin West
}

\author{
Immo Warntjes
}

\section{Introduction}

Ever since the invention of the derogatory term 'Middle Ages' by $15^{\text {th }}$-century Humanists, the period between the end of the Western Roman Empire and the emergence of a new Empire under Charlemagne has been variously interpreted. The Mediterranean as the centre of the ancient world is the focal point of any of these views. Gibbon considered the old world order to have collapsed with the fall of Rome in the fifth century, ${ }^{1}$ while Pirenne stressed that the truly seismic shift in the Mediterranean was the rise of Islam in the seventh. ${ }^{2}$ Since the 1960 s, scholars have tended to downplay the importance of watersheds and opt for more generic models of transition. ${ }^{3}$ From the perspective of the history of science, certainly a substantial shift occurred in the sixth century in what was to become the Latin West. Greek lost its currency as the language of learning, and texts written in that language were known only by name in the following five centuries until their recovery through Arabic channels in the so-called Renaissance of the $12^{\text {th }}$ century. ${ }^{4}$ The centres of learning shifted from secular institutions to the rapidly growing monasteries, which monopolized access to knowledge until the rise of the universities in the $11^{\text {th }}$ century. ${ }^{5}$ For six centuries, from the sixth to the $11^{\text {th }}$, learning was therefore decidedly Christian in character in the Latin West. ${ }^{6}$

The calendar tradition fits this pattern well. In this article, the term calendar will be used for a tabulation of the 365 days of the Julian calendar year in grid format, with one line for each calendar

\footnotetext{
${ }^{1}$ E. Gibbon, The History of the Decline and Fall of the Roman Empire, 6 vols (London, 1776-89, repr. 2005). I gratefully acknowledge that this research was funded by the Irish Research Council as part of the Laureate Consolidator Award Scheme.

${ }^{2}$ H. Pirenne, Mahomet et Charlemagne (Paris, 1937).

${ }^{3}$ One of the earliest examples is the volume L.T. White (ed.), The Transformation of the Roman World: Gibbon's Problem after Two Centuries (Berkley: University of California Press, 1966); more recently, see, e.g., C. Wickham, The Inheritance of Rome: A History of Europe from 400 to 1000 (London: Allan Lane, 2009); I.N. Wood, The Transformation of the Roman West (Leeds: Arc Humanities Press, 2018); and the review of the concept by W. Pohl, 'The transformation of the Roman world revisited', in J. Kreiner and H. Reimitz (eds), Motions of Late Antiquity: Essays on Religion, Politics, and Society in Honour of Peter Brown (Turnhout: Brepols, 2016), pp. 45-61.

${ }^{4}$ C.H. Haskins, The Renaissance of the Twelfth Century (Cambridge: Harvard University Press, 1927), an influential and sweeping overview that should be read in connection with his detailed analyses collected in Studies in the History of Mediaeval Science (Cambridge, Mass.: Harvard University Press, 1924). For an excellent recent overview, see the two chapters 'Translation and transmission of Greek and Islamic science to Latin Christendom' and 'The twelfth-century renaissance' by C. Burnett in D.C. Lindberg and M.H. Shank (eds), The Cambridge History of Science, vol. 2: Medieval Science (Cambridge: Cambridge University Press, 2015), pp. 341-84.

${ }^{5}$ See especially the classic by P. Riché, Les écoles et l'enseignement dans l'Occident chrétien: de la fin du Ve siècle au milieu du XI siècle (Paris: Aubier Montaigne, 1979).

${ }^{6}$ See especially the studies by J.J. Contreni, e.g. 'The Carolingian Renaissance: education and literary culture', in R. McKitterick (ed.), The New Cambridge Medieval History, vol. 2: c.700-c.900 (Cambridge: Cambridge University Press, 1995), pp. 709-57; 1013-24: pp. 725-47; 'Learning for God: education in the Carolingian Age', Journal of Medieval Latin 24 (2014), pp. 89-130, esp. 94-112.
} 
date, organized according to the 12 months of the Julian calendar year. ${ }^{7}$ The format is well-known to a $21^{\text {st }}$-century audience, since it has not changed since the days of Gaius Julius Caesar in 46 BC: We still have the same months with the same number of days (January 31, February 28, March 31, April 30, May 31, June 30, July 31, August 31, September 30, October 31, November 30, December 31). What has changed is the place of the bissextile or leap-day, traditionally on 24 February, but today added to the end of February as its $29^{\text {th }}$ day. ${ }^{8}$ And, more importantly, the configuration of dates in each month; while we today are used to a consecutive count of days from 1 to 28,30 , or 31 , the Julian calendar months were designed around three marker day, the Calends (invariably the first day of the month), the Nones (fifth or seventh day of the month), and the Ides (thirteenth or fifteenth day of the month). From these marker days, the days were counted backwards (e.g.: Ides of March = 15 March, second day before the Ides of March = 14 March, etc.).

Table 1: Grid of the Julian calendar

\begin{tabular}{|c|c|c|c|c|c|c|c|c|c|c|c|c|}
\hline & Jan & Feb & Mar & Apr & May & Jun & Jul & Aug & Sep & Oct & Nov & Dec \\
\hline 1 & Kal & $\mathrm{Kal}$ & Kal & Kal & Kal & Kal & Kal & Kal & Kal & Kal & Kal & Kal \\
\hline 2 & IV No & IV No & VI No & IV No & VI No & IV No & VI No & IV No & IV No & VI No & IV No & IV No \\
\hline 3 & III No & III No & V No & III No & V No & III No & V No & III No & III No & V No & III No & III No \\
\hline 4 & II No & II No & IV No & II No & IV No & II No & IV No & II No & II No & IV No & II No & II No \\
\hline 5 & $\begin{array}{l}\text { Nona } \\
\mathrm{e}\end{array}$ & $\begin{array}{l}\text { Nona } \\
\mathrm{e}\end{array}$ & III No & $\begin{array}{l}\text { Nona } \\
\mathrm{e}\end{array}$ & III No & $\begin{array}{l}\text { Nona } \\
\mathrm{e}\end{array}$ & III No & $\begin{array}{l}\text { Nona } \\
\mathrm{e}\end{array}$ & $\begin{array}{l}\text { Nona } \\
\mathrm{e}\end{array}$ & III No & $\begin{array}{l}\text { Nona } \\
\mathrm{e}\end{array}$ & $\begin{array}{l}\text { Nona } \\
\mathrm{e}\end{array}$ \\
\hline 6 & VIII Id & VIII Id & II No & VIII Id & II No & VIII Id & II No & VIII Id & VIII Id & II No & VIII Id & VIII Id \\
\hline 7 & VII Id & VII Id & $\begin{array}{l}\text { Nona } \\
\mathrm{e}\end{array}$ & VII Id & $\begin{array}{l}\text { Nona } \\
\mathrm{e}\end{array}$ & VII Id & $\begin{array}{l}\text { Nona } \\
\mathrm{e}\end{array}$ & VII Id & VII Id & $\begin{array}{l}\text { Nona } \\
\mathrm{e}\end{array}$ & VII Id & VII Id \\
\hline 8 & VI Id & VIId & VIII Id & VI Id & VIII Id & VIId & VIII Id & VIId & VI Id & VIII Id & VI Id & VI Id \\
\hline 9 & V Id & VId & VII Id & VId & VII Id & VId & VII Id & V Id & VId & VII Id & VId & V Id \\
\hline $\begin{array}{l}1 \\
0\end{array}$ & IV Id & IV Id & VI Id & IV Id & VIId & IV Id & VI Id & IV Id & IV Id & VI Id & IV Id & IV Id \\
\hline $\begin{array}{l}1 \\
1\end{array}$ & III Id & III Id & V Id & III Id & V Id & III Id & V Id & III Id & III Id & V Id & III Id & III Id \\
\hline $\begin{array}{l}1 \\
2\end{array}$ & II Id & II Id & IV Id & II Id & V Id & II Id & IV Id & II Id & II Id & IV Id & II Id & II Id \\
\hline $\begin{array}{l}1 \\
3 \\
\end{array}$ & Idus & Idus & III Id & Idus & III Id & Idus & III Id & Idus & Idus & III Id & Idus & Idus \\
\hline $\begin{array}{l}1 \\
4 \\
\end{array}$ & XIX KI & XVI KI & II Id & $\begin{array}{l}\text { XVIII } \\
\mathrm{KI} \\
\end{array}$ & II Id & $\begin{array}{l}\mathrm{XVIII} \\
\mathrm{KI} \\
\end{array}$ & II Id & XIX KI & $\begin{array}{l}\mathrm{XVIII} \\
\mathrm{KI} \\
\end{array}$ & II Id & $\begin{array}{l}\mathrm{XVIII} \\
\mathrm{KI} \\
\end{array}$ & XIX KI \\
\hline $\begin{array}{l}1 \\
5\end{array}$ & $\begin{array}{l}\text { XVIII } \\
\mathrm{KI}\end{array}$ & XV KI & Idus & $\begin{array}{l}\mathrm{XVII} \\
\mathrm{KI}\end{array}$ & Idus & $\begin{array}{l}\text { XVII } \\
\mathrm{KI}\end{array}$ & Idus & $\begin{array}{l}\text { XVIII } \\
\mathrm{KI}\end{array}$ & $\begin{array}{l}\mathrm{XVII} \\
\mathrm{KI}\end{array}$ & Idus & $\begin{array}{l}\text { XVII } \\
\mathrm{KI}\end{array}$ & $\begin{array}{l}\text { XVIII } \\
\mathrm{KI}\end{array}$ \\
\hline 1 & XVII & XIV KI & XVII & XVI KI & XVII & XVI KI & $X V I I$ & $X V I I$ & XVI KI & XVII & XVI KI & XVII \\
\hline
\end{tabular}

\footnotetext{
${ }^{7}$ It is important to stress here the difference between a martyrology and a calendar: a martyrology lists saints's feastdays by calendar date; typically, one line is not enough for each date to include all the saints of that date, so that the visual format of a martyrology resembles a prose text more than the tabular format of a calendar; also, if no saint was listed for a given Julian calendar date, that date was not recorded. Early medieval calendars cut the list of saints short, concentrating only on the most important ones in the view of the author; but a calendar always provided a full grid of all 365 days. In this definition, a list of exclusively Christian feastdays by calendar dates is a martyrology; if additional elements are included (typically the computistical, astronomical, and prognostic data discussed below) and the format is a recognizable grid, it is a calendar.

${ }^{8}$ The minimal change (at least in application) from the Julian to the Gregorian calendar by omitting three bissextile days in a given 400-year period (in years of full hundreds not divisible by 4 ) is obviously of no relevance here.
} 


\begin{tabular}{|c|c|c|c|c|c|c|c|c|c|c|c|c|}
\hline 6 & $\mathrm{KI}$ & & $\mathrm{KI}$ & & $\mathrm{KI}$ & & $\mathrm{KI}$ & $\mathrm{KI}$ & & $\mathrm{KI}$ & & $\mathrm{KI}$ \\
\hline $\begin{array}{l}1 \\
7\end{array}$ & XVI KI & XIII KI & XVI KI & XV KI & XVI KI & XV KI & XVI KI & XVI KI & XV KI & XVI KI & XV KI & XVI KI \\
\hline $\begin{array}{l}1 \\
8\end{array}$ & XV KI & XII KI & XV KI & XIV KI & XV KI & XIV KI & XV KI & XV KI & XIV KI & $\mathrm{XV} \mathrm{KI}$ & XIV KI & XV KI \\
\hline $\begin{array}{l}1 \\
9\end{array}$ & XIV KI & $\mathrm{XI} \mathrm{KI}$ & XIV KI & XIII KI & XIV KI & XIII KI & XIV KI & XIV KI & XIII KI & XIV KI & XIII KI & XIV KI \\
\hline $\begin{array}{l}2 \\
0\end{array}$ & XIII KI & X KI & XIII KI & XII KI & XIII KI & XII KI & XIII KI & XIII KI & XII KI & XIII KI & XII KI & XIII KI \\
\hline $\begin{array}{l}2 \\
1\end{array}$ & XII KI & IX KI & XII KI & $\mathrm{XI} \mathrm{KI}$ & XII KI & $\mathrm{XI} \mathrm{KI}$ & XII KI & XII KI & $\mathrm{XI} \mathrm{KI}$ & XII KI & XI KI & XII KI \\
\hline $\begin{array}{l}2 \\
2 \\
\end{array}$ & XI KI & VIII KI & XI KI & $\mathrm{X} \mathrm{KI}$ & $\mathrm{XI} \mathrm{KI}$ & $\mathrm{X} \mathrm{KI}$ & XI KI & XI KI & $\mathrm{X} \mathrm{KI}$ & $\mathrm{XI} \mathrm{KI}$ & $\mathrm{X} \mathrm{KI}$ & XI KI \\
\hline $\begin{array}{l}2 \\
3\end{array}$ & $\mathrm{X} \mathrm{Kl}$ & VII KI & $\mathrm{X} \mathrm{KI}$ & IX KI & $\mathrm{X} \mathrm{KI}$ & IX KI & $\mathrm{X} \mathrm{KI}$ & $\mathrm{X} \mathrm{KI}$ & IX KI & $\mathrm{X} \mathrm{KI}$ & IX KI & $\mathrm{X} \mathrm{Kl}$ \\
\hline $\begin{array}{l}2 \\
4 \\
\end{array}$ & IX KI & VI KI & IX KI & VIII KI & IX KI & VIII KI & IX KI & IX KI & VIII KI & IX KI & VIII KI & IX KI \\
\hline $\begin{array}{l}2 \\
5\end{array}$ & VIII KI & V KI & VIII KI & VII KI & VIII KI & VII KI & VIII KI & VIII KI & VII KI & VIII KI & VII KI & VIII KI \\
\hline $\begin{array}{l}2 \\
6 \\
\end{array}$ & VII KI & IV KI & VII KI & VI KI & VII KI & VI KI & VII KI & VII KI & $\mathrm{VI} \mathrm{KI}$ & VII KI & VI KI & VII KI \\
\hline $\begin{array}{l}2 \\
7\end{array}$ & VI KI & III KI & VI KI & V KI & VI KI & V KI & $\mathrm{VI} \mathrm{KI}$ & VI KI & V KI & VI KI & V KI & VI KI \\
\hline $\begin{array}{l}2 \\
8\end{array}$ & V KI & II KI & V KI & IV KI & $\mathrm{V} \mathrm{KI}$ & IV KI & V KI & $\mathrm{V} \mathrm{KI}$ & IV KI & V Kl & IV KI & V KI \\
\hline $\begin{array}{l}2 \\
9 \\
\end{array}$ & IV KI & & IV KI & III KI & IV KI & III KI & IV KI & IV KI & III KI & IV KI & III KI & IV KI \\
\hline $\begin{array}{l}3 \\
0\end{array}$ & III KI & & III KI & II KI & III KI & II KI & III KI & III KI & II KI & III KI & II KI & III KI \\
\hline $\begin{array}{l}3 \\
1 \\
\end{array}$ & II KI & & II KI & & II KI & & II KI & II KI & & II KI & & II KI \\
\hline
\end{tabular}

Roman calendar representations in grid format are older than Caesar's reform, as evidenced by the famous Fasti antiates maiores. The evidence becomes more numerous from Augustus' reign. However, none of these inscriptions, paintings, or mosaics survive in full. ${ }^{9}$ The oldest calendar of the Julian type that is transmitted complete, in later manuscript copies, formed part of the so-called Chronograph of 354 (i.e. four centuries after Caesar's reform), which also contained, among other items, a depiction of the four most important cities of the late Roman Empire (Rome, Alexandria, Constantinople, and Trier), a list of birthdays of Roman emperors, depictions of the planetary weekdays and zodiac signs with commentaries, a list of consuls from the foundation of the Republic (509 BC) to AD 354, a list of Easter dates AD 312-411, a list of Roman prefects for 254-354, a list of death dates and burial places of popes organized by calendar dates starting with Christmas, a list of

\footnotetext{
${ }^{9}$ A. Degrassi, Inscriptiones Italiae 13: fasti et elogia, fasciculus 2: Fasti anni Numani et Iuliani, accedunt ferialia, menologia rustica, parapegmata (Rome: Libreria delle Stato, 1963), for earlier calendar fragments; see also the summary in M.R. Salzmann, On Roman Time: The Codex-calendar of 354 and the Rhythms of Urban Life in Late Antiquity (Berkeley: University of California Press, 1990), pp. 7-8.
} 
Christian martyrs likewise arranged, a list of popes from Peter to Liberius with commentary. ${ }^{10}$ The calendar itself had the dates centred. ${ }^{11}$ To the left were three alphabetic columns, representing the synodic lunar month, the seven- and the eight-day week respectively. To the right one finds important information for the respective dates, ranging from heathen and imperial feast or memorial days through senate meetings to astronomical and astrological data. Thus, the calendar itself shows no Christian features, but the context of its production with papal and martyr lists as well as Easter dates certainly does.

[Figure 3.1: Burgerbibliothek Bern, Cod. 108, fol. 1r: December page]

A second calendar from Late Antiquity survives, composed by one Polemius Silvius in AD 448/9 for Bishop Eucherius of Lyon. Polemius also added texts to his calendar, most notably a list of Emperors and Roman provinces. But in his work, the calendar took centre stage. ${ }^{12}$ Polemius had limited interest in astronomical or technical calendrical phenomena. There are no alphabetic columns representing the synodic lunar month or the weekday, his calendar immediately displays the Julian calendar dates as the first column. This left considerable space to the right, which Polemius populated not only with important Roman events, but also with major Christian ones, like the crucifixion and resurrection of Christ on 25 and 27 March respectively. Rather than recording the entry of the sun in the respective zodiac signs, Polemius had a strong interest in information related to agriculture: weather prognostics, solstices and equinoxes, beginnings of the seasons.

After Polemius Silvius's calendar of AD 448/9, the next surviving witness to this genre is Willibrord's calendar preserved in Paris BnF Lat. 10837. ${ }^{13}$ Willibrord grew up in Northumbria, received his education in the strongly Roman-minded monastery of Ripon under Wilfrid (later of York)'s tutelage. ${ }^{14}$ When Wilfrid was expelled from Northumbria in AD 678, his student Willibrord left for

\footnotetext{
${ }^{10}$ No manuscript transmitting the entire Chronograph of AD 354 survives, its original extent needs to be reconstructed from the just over 10 codices that evidently contain part of the work. See now R.W. Burgess, 'The Chronograph of 354: Its Manuscripts, Contents, and History', Journal of Late Antiquity 5 (2012), pp. 34596.

${ }^{11}$ The standard edition of the calendar of 354 (in parallel with the one by Polemius Silvius to be discussed shortly) is T. Mommsen, Corpus Inscriptionum Latinarum, vol. 1 (Berlin, 1863, 2nd ed. 1893), pp. 334-57. A new edition with extensive commentary has been produced by J. Divjak and W. Wischmeyer, Das Kalenderbuch von 354: Der Chronograph des Filocalus, 2 vols (Wien: Holzhausen, 2014), vol. 1, pp. 157-344; for criticism of this edition see R.W. Burgess, 'The New Edition of the Chronograph of 354: A Detailed Critique', Zeitschrift für antikes Christentum 21 (2017), pp. 383-415, esp. 391-401, with response by the authors ibid., pp. 416-18.

${ }^{12}$ For the ed. of Polemius' calendar, see previous note. It survives in only one manuscript, Brussels KBR 10615729, 93r-95r (Trier, saec. XII).

${ }^{13}$ Paris BnF Lat. 10837, 34v-40r (Echternach?, saec. VIIIInf; available online at:

https://gallica.bnf.fr/ark:/12148/btv1b6001113z.r=10837?rk=150215;2, accessed 13 August 2020). A facsimile edition of the calendar was produced by H.A. Wilson, The Calendar of St. Willibrord (Woodbridge: Henry Bradshaw Society, 1918).

${ }^{14}$ For the relationship between Wilfrid and Willibrord, see especially Stephen of Ripon, Vita Wilfridi ch. 26 (ed. and trans. B. Colgrave, The Life of Bishop Wilfrid by Eddius Stephanus [Cambridge: Cambridge University Press, 1927, repr. 1985], pp. 52-53). Willibrord's 'Romanisim' has recently been under severe scrutiny; cf. especially A. van Berkum, 'Willibrord en Wilfrid: een oderzoek naar hun wederzijdse betrekkingen', Sacris Erudiri 23 (1978), pp. 347-417; the overview by E. Honée, 'St Willibrord in recent historiography', in P.N. Holtrop and H. McLeod (eds), Missions and missionaries (Woodbridge: Boydell, 2000), pp. 16-31; and M. Ziegler, 'The Ripon connection? Willibrord, Wilfrid, and the mission to Frisia', The Heroic Age 6 (2003). Note that even if Willibrord
} 
Ireland, ${ }^{15}$ whose monasteries boasted an older tradition and more expertise in Christian learning. ${ }^{16}$ From Ireland, more precisely the monastery of Rath Melsigi, Willibrord initiated his Frisian mission in AD $690 .{ }^{17}$ A mission needed texts. Not much is known about Willibrord's Handbibliothek. ${ }^{18}$ It certainly included the basics for keeping track of liturgical time: an Easter table, ${ }^{19}$ a basic collection of calendrical algorithms (for, e.g., calculating the $A D$ date of any given year, the weekday and lunar age of any given calendar date),${ }^{20}$ and the aforementioned calendar.

The focus of the calendar itself, in the first and subsequent hands, is strongly martyrological, not computistical. It reflects Willibrord's Northumbrian and Irish background, commemorating, e.g., the Deiran kings Edwin (†AD 633) and Oswine (†AD 651), the Bernician kings Oswald (†AD 642) and Ecgfrith ( $+A D$ 685), Bishop Cuthberht of Lindisfarne (†AD 687), the Irish Saints Patrick († $5^{\text {th }}$ cent.?), Brigit ( $+6^{\text {th }}$ cent.?), and Columba ( $\left.+A D 593\right)$, and also the Irish missionary Bishop Áedán of Lindisfarne (†AD 651). His debt to the Roman Christianisation of Anglo-Saxon England is highlighted by recording Bishop Paulinus of York (†AD 644) and Theodore of Canterbury (†AD 690). His own missionary interest is reflected in the listing of the two Hewalds who were slaughtered when trying to convert the Saxons shortly before Willibrord came to the continent. The computistical information is very limited: the original composition included only synodic lunar letters and a numerical weekday sequence in the left-hand column. The Isidorian beginnings of the seasons (with their calculated lengths) and a note for the bissextile day on 24 February were added by a slightly later hand. In Willibrord's design, the martyrological entries had centre stage, the calendar tradition had turned fully Christian.

From Willibrord's calendar onwards, there is no break in the medieval calendar tradition, they become more frequent in the eighth century, and then mushroomed in the ninth. Though Willibrord's calendar is the first witness of this genre in the Middle Ages, it is not considered the 'prototype' for the medieval calendar tradition. According to Arno Borst, who collated 252 calendars

is, rightly, pulled out of a rather one-dimensional Anglo-Saxon/Roman perspective, this does not affect Willibrod's views on Easter, which were strongly and exclusively Roman/Dionysiac.

${ }^{15} \mathrm{Cf}$. especially A. Hauck, Kirchengeschichte Deutschlands, vol. 1 (3rd and 4th ed., Leipzig: J.C. Hinrichs'sche Buchhandlung, 1904), pp. 434-35; C. Wampach, Geschichte der Grundherrschaft Echternach im Frühmittelalter, 2 vols (Luxemburg: Luxemburger Kunstdruckerei, 1929-30), vol 1, pp. 20-24; W. Levison, 'St. Willibrord and his place in history', Durham University Journal 32 (1940), pp. 23-41; repr. in idem, Aus rheinischer und fränkischer Frühzeit: ausgewählte Aufsätze (Düsseldorf: Schwann, 1948), pp. 314-29, esp. 315-16. Critical about this reconstruction of events, van Berkum, 'Willibrord en Wilfrid', pp. 385-91; Ziegler, 'Ripon connection?'. ${ }^{16}$ It is enough here to refer to Aldhelm's and Bede's famous quotes in Epistulae ad Wihtfridum and ad Ehfridum (ed. R. Ehwald in MGH Auct. ant. vol. 15, pp. 479-80, 486-94) and Historia ecclesiastica ch. III 27 (C. Plummer, Baedae opera historica, 2 vols [Oxford: Oxford University Press, 1896], vol. 1, p. 192) respectively. ${ }^{17}$ Bede, Historia ecclesiastica ch. V 9-10 (Plummer, Baedae opera historica, vol. 1, pp. 296-301). The year is suggested by Bede, Historia ecclesiastica ch. V 8 (Plummer, Baedae opera historica, vol. 1, p. 294), and is explicit in the marginal note to the November page of Willibrord's calendar (Paris BnF Lat. 10837, 40v). ${ }^{18} \mathrm{Cf}$. the well-established Handbibliothek of Willibrord's contemporary Boniface as reconstructed by $\mathrm{H}$. Schüling, 'Die Handbibliothek des Bonifatius', Archiv für Geschichte des Buchwesens 4 (1961-3), pp. 286-349. ${ }^{19}$ The same manuscript that contains Willibrord's calendar (Paris BnF Lat. 10837) also includes an Easter table, which falls into four successive stages of composition: 1) AD 684-702: fol. 44r; this single sheet Willibrord brought from Ireland to the Continent; cf. D. Ó Cróinín, 'Rath Melsigi, Willibrord, and the Earliest Echternach Manuscripts', Peritia 3 (1984), pp. 17-49, repr. in idem, Early Irish History and Chronology (Dublin: Four Courts, 2003), pp. 145-72 (with an appendix by T. Fanning), pp. 155-56; 2) AD 703-721: fol. 40v; 3) AD 722-759: fol. 41r-v; 4) AD 760-797: fol. 43r-v.

${ }^{20}$ London BL Cotton Caligula A XV, 73r-80r (north-eastern France?, AD 743?); see I. Warntjes, 'The Computus Cottonianus of AD 689: a computistical formulary written for Willibrord's Frisian mission', in I. Warntjes and D. Ó Cróinín (eds), The Easter Controversy of Late Antiquity and the Early Middle Ages: Its Manuscripts, Texts, and Tables (Turnhout: Brepols, 2011), pp. 173-212. 
from the eighth to the twelfth centuries in a monumental 3-volume study published in $2001,{ }^{21}$ three aspects define an early medieval calendar:

a) Liturgical / martyrological entries

b) (Bedan) computistical information

c) Astronomical excerpts (especially Pliny)

In Borst's opinion, the first calendar to show all three features fully developed was a calendar of $A D$ 789 , produced in the royal abbey of Lorsch, preserved in a Prüm manuscript of the AD 840s. ${ }^{22}$ Borst argues that this type of calendar radiated out from the Frankish heartland (with the Aachen palace school at its centre) to all areas of the Empire as part of Charlemagne's grand design of centralizing power and reforming the education system.

Borst's theory was soon challenged, principally by pushing the construction of the 'prototype' calendar back in time and space. Brigitte Englisch places its design in Soissons in the mid-eighth century, while Paul Meyvaert credited the Anglo-Saxon priest-monk Bede with its invention as a prefix to his computistical textbook De temporum ratione of AD 725. ${ }^{23}$ All three theories (Borst's, Englisch's, Meyvaert's) have their problems, but here is not the space to discuss this in detail. ${ }^{24}$ What

${ }^{21}$ A. Borst, Der karolingische Reichskalender und seine Überlieferung bis ins 12. Jahrhundert, 3 vols (Hannover: Hahn, 2001), pp. XIII-XX, LIII, 54-333; Borst added 13 more calendars in Der Streit um den karolingischen Kalender (Hannover: Hahn, 2004), pp. 129-58.

${ }^{22}$ A. Borst, Die karolingische Kalenderreform (Hannover: Hahn, 1998), esp. pp. 245-99.

${ }^{23} \mathrm{~B}$. Englisch, Zeiterfassung und Kalenderprogrammatik in der frühen Karolingerzeit: das Kalendarium der Hs. Köln DB 83-2 und die Synode von Soissons 744 (Stuttgart: Thorbeke, 2002); P. Meyvaert, 'Discovering the calendar (annalis libellus) attached to Bede's own copy of De temporum ratione', Analecta Bollandiana 120 (2002), pp. 5-64. Borst responded to this criticism in his beautiful little book on Der Streit um den karolingischen Kalender.

${ }^{24}$ Borst's model of calendrical thought radiating out from the Carolingian centre has been criticised for the related umbrella subject, computus; see I. Dobcheva, 'The umbrella of Carolingian computus', in M.J. Muñoz Jiménez, P. Cañizares Ferriz, and C. Martin (eds), La compilación del saber en la edad media (Porto: Fédération Internationale des Instituts d'Études Médiévales, 2013), pp. 211-30; I. Warntjes, 'Köln als naturwissenschaftliches Zentrum in der Karolingerzeit: die frühmittelalterliche Kölner Schule und der Beginn der fränkischen Komputistik', in H. Finger and H. Horst (eds), Mittelalterliche Handschriften der Kölner Dombibliothek, Viertes Symposion (Köln: Erzbischöfliche Diözesan- und Dombibliothek, 2012), pp. 41-96; J.T. Palmer, 'Computus after the paschal controversy of AD 740', in I. Warntjes and D. Ó Cróinín (eds), The Easter Controversy of Late Antiquity and the Early Middle Ages: Its Manuscripts, Texts, and Tables (Turnhout: Brepols, 2011), pp. 213-41; J.T. Palmer, 'Calculating time and the end of time in the Carolingian world, c. 740-820', English Historical Review 126 (2011), pp. 1307-31. Englisch's theory of a crisis of time-reckoning in Francia in the AD 740 providing the stimulus for the early medieval calendar tradition is based on three observations, all of them wrong: 1) The decrees of the Council of Soisson of 744 (MGH Conc. vol. 2,1, p. 33) were signed off on 2 March, luna 14 (full moon), which was the factual moon contradicting the calculated one (pp. 84-85); the factual moon was full, however, on 3 March

(http://www.astropixels.com/ephemeris/phasescat/phases0701.html, accessed 13 August 2020), and thus coincided with the calculated one according to both Victorius and Dionysius; 3 March is also the date of the decrees of the council of Soisson of AD 744, as the best manuscript (V) explicitly recorded this date (already pointed out by B. Krusch, 'Das Datum des Concils von Soissons 744 März 3.', Neues Archiv der Gesellschaft für ältere deutsche Geschichtsforschung 30 [1905], pp. 708-9); 2) A total solar eclipse was visible in Francia on 1 April 740 (pp. 87-88); however, this eclipse was not visible in western Europe, its path of totality was from central Africa through Pakistan to Mongolia and Korea (https://eclipse.gsfc.nasa.gov/SEsearch/SEsearchmap.php?Ecl=07400401, accessed 13 August 2020; this is already evident from Oppolzer's 1887 Canon der Finsternisse that Englisch cites); 3) Englisch claims that her key witness, the calendar in Cologne DB 83-II, 72v-76r (Cologne, AD 805), contains a substantial Victorian computistical element, if it should not be classified as Victorian (pp. 33-40); this is not the case (see n. 51). Meyvaert's theory is problematic on at least three levels: 1 ) Bede mentions the calendar prefixed to his De 
is important for the present article is the agreement of all three most recent scholars in the existence of a 'prototype' calendar and their assessment of the general genesis of such a prototype, wherever it was first produced.

The starting point of this narrative is the Gregorian mission under Augustine, sent from Rome to Anglo-Saxon England (more precisely Kent) in AD 596. This initiated a gradual south to north spread of 'Roman' Christianity in Britain, which eventually clashed in Northumbria with a 'Celtic' version of Christianity, introduced there from the Irish monastery of lona (off the cost of modern-day southwestern Scotland) in AD 635. ${ }^{25}$ The problem was resolved at the famous Synod or Council of Whitby of AD 664, which brought 'Roman' unity to all of Anglo-Saxon England, or so Bede and Stephen of Ripon want to make us believe. ${ }^{26}$ Instrumental in this process were Benedict Biscop, founder of Bede's monastery of Wearmouth, and the aforementioned Wilfrid. Both of them frequently travelled to Rome, and returned from the Holy See with the latest publications and the classics to stock their newly created libraries at home. Bede, when preparing his opus magnum, the Historia ecclesiastica gentis Anglorum, of AD 731 or shortly thereafter, drew on similar channels of book transfer from Rome to Northumbria. This import of Roman literature also included a calendar similar to that of Polemius Silvius. Bede, in his History of the Abbots of Wearmouth and Jarrow, relates that Benedict Biscop had brought a Codex cosmographiorum from Rome, which Abbot Ceolfrith then presented to King Aldfrith of Northumbria in exchange for a considerable portion of land, presumably in the AD 690s. ${ }^{27}$ This codex contained a calendar, of which the details are not known; the inference is that it must have resembled the one composed by Polemius Silvius. This model informed the Northumbrian engagement with calendars in the first half of the eighth century,

temporum ratione explicitly only in three chapters $(19,23,41)$, indicating that it incorporated sidereal and synodic lunar letters, and a reference to the bissextile day on 24 February; there is no conclusive direct evidence that anything else was part of Bede's calendar; 2) some of the computistical features discussed by Meyvaert do not represent Bedan thought (e.g., Bede does not mention any of the moveable feasts dependent on Easter, like Pentecost; Bede favours the saltus lunae on 25 November, not 21 March); 3) the study misses an analytical corrective: the computistical calendar entries are compared to Bede's De temporum ratione only, not considering the earlier and contemporary Irish and Frankish texts.

${ }^{25}$ The terms 'Celtic' and 'Roman' are obviously problematic in this context, as the early Middle Ages neither knew a monolithic 'Celtic Church', nor was 'Roman dogma' considered binding by the Western churches. As this article is principally concerned with calendrical/computistical theory, the use of Easter calculations may illustrate this point: The 'Celtic' Easter reckoning, called latercus and invented by Sulpicius Severus in Gaul, was abandoned by the Celtic gentes of Britain and Ireland not at one synod binding for all, but rather in a slow process from southern Ireland in AD 633 to northern Ireland towards the end of the seventh century, Pictland in AD 710, lona in AD 716, and the Britons of Wales and elsewhere in AD 768; cf. p. 94 n. 176. Roman 'unity' remained a myth as long as the Victorian and the Dionysiac reckoning, both claiming papal sanction, co-existed until the end of the eighth century.

${ }^{26}$ Our knowledge of the Synod of Whitby derives exclusively from Stephen's and Bede's highly biased narratives: Stephen of Ripon, Vita Wilfridi ch. 10 (Colgrave, Life of Bishop Wilfrid, pp. 20-23); Bede, Historia ecclesiastica ch. III 25 (Plummer, Baedae opera historica, vol. 1, pp. 181-89). For the political background, see R. Abels, 'The council of Whitby: a study in early Anglo-Saxon politics', Journal of British Studies 23 (1983), pp. 1-25. For the theological/scientific debate, see now especially L. Holford-Strevens, 'Marital discord in Northumbria: Lent and Easter, his and hers', in I. Warntjes and D. Ó Cróinín (eds), Computus and Its Cultural Context in the Latin West, AD 300-1200 (Turnhout: Brepols, 2010), pp. 143-58; E.T. Dailey, 'To choose one Easter from three: Oswiu's decision and the Northumbrian Synod of AD 664', Peritia 26 (2015), pp. 47-64. A good overview is provided by C. Corning, The Celtic and Roman Traditions: Conflict and Consensus in the Early Medieval Church (New York: Palgrave Macmillan, 2006), pp. 112-29.

${ }^{27}$ Bede, Historia abbatum ch. 15 (ed. Plummer, Baedae opera historica, vol. 1, pp. 379-80; see now the new edition and translation by C. Grocock and I.N. Wood, Abbots of Wearmouth and Jarrow [Oxford: Clarendon Press, 2013], pp. 56-59). For the Codex cosmographiorum, see Meyvaert, 'Discovering', pp. 16-25; and also G. Henderson, Vision and Image in Early Christian England (Cambridge: Cambridge University Press, 1999), pp. 94-96. 
especially Bede. Directly from Northumbria, this calendar tradition entered the Frankish kingdoms, possibly as part of Alcuin's travel library in the AD 770s, probably earlier. The exact shape and form of this tradition remains debatable. But the principal early medieval route of transmission of the calendar genre therefore was from Rome through Northumbria to the Frankish heartland.

This theory leaves little room for alternative readings of the origin and spread of early medieval calendars. First, it does not consider for the calendar tradition the second well-established route of transmission for late antique and early medieval texts: from Visigothic Spain to Ireland, and from Ireland to Northumbria on the one hand, and through Brittany and the Loire valley or north-eastern France to the Frankish heartland and then further south to modern-day Switzerland and northern Italy on the other. ${ }^{28}$ I will deal with this question in a separate publication. Second, for the creation of an early medieval calendar, no Roman model was needed. It is this second aspect that the present article is concerned with.

\section{Calendrical knowledge in seventh-century Ireland}

It is a still very popular, wrong assumption that medieval calendrical science, called by its Latin term computus or computistics in English, began with Bede ( $+A D$ 735). Bede was no isolated genius. Quite the contrary, he drew on a decades-old tradition establish in Ireland. ${ }^{29}$ Ireland benefitted from a substantial import of texts from Visigothic Spain, and by the AD 630s, as Cummian's letter attests, had a more or less full set of late antique texts dealing with the question of how to best calculate the date of Easter and related issues. ${ }^{30}$ The principal challenge of Easter calculation was to press synodic lunar months (the period from one new or full moon to the next) of $c .29 .530589$ day-length into a mathematical model that would align with the Julian calendar of $3651 / 4$ days. The solution was a 19year lunar cycle of 6939 3/4 days (19 Julian calendar years of 365 1/4 days: 19x365 1/4 = 6939 3/4 days; 235 lunar months averaging at c.29.530851, distributed in the following way: 19 lunar years of 12 lunar months alternating between 30 and 29 days $+43 / 4$ bissextile days +7 intercalated lunar months of 30

\footnotetext{
${ }^{28}$ For this route of transmission (or parts of it), especially for computistical texts, see C.W. Jones, Bedae opera de temporibus (Cambridge: The Medieval Academy of America, 1943), pp. 105-13; D. Ó Cróinín, 'The Irish provenance of Bede's computus', Peritia 2 (1983), pp. 229-47; repr. in idem, Early Irish History, pp. 173-90; idem, 'Bede's Irish computus', in ibid., pp. 201-12; Warntjes, Munich Computus, pp. XCVII-CVI; idem, 'The continuation of the Alexandrian Easter table in seventh-century Iberia and its transmission to ninth-century Francia (Isidore, Etymologiae 6.17)', Revue d'Histoire des Textes n.s. 13 (2018), pp. 185-94.

${ }^{29}$ For pre-Bedan Irish computistics, see especially the overviews in I. Warntjes, 'Irische Komputistik zwischen Isidor von Sevilla und Beda Venerabilis: Ursprung, karolingische Rezeption und Forschungsperspektiven', Viator 42 Multilingual (2011), pp. 1-31; idem, 'Seventh-century Ireland: the cradle of medieval science?', in M. Kelly and C. Doherty (eds), Music and the Stars: Mathematics in Medieval Ireland (Dublin: Four Courts, 2013), pp. 44-72; I. Warntjes, 'Computus as scientific thought in Ireland and the early medieval West', in R. Flechner and S. Meeder, The Irish in Early Medieval Europe: Identity, Culture and Religion (New York: Macmillan, 2016), pp. 158-78. For Bede's debt to Irish thought, see now M. Mac Carron, 'Bede, Irish computistica and Annus Mundi', Early Medieval Europe 23 (2015), pp. 290-307; eadem, Bede and Time: Computus, Theology and History in the Early Medieval World (London: Routledge, 2019), pp. 20-47. Cf. also my review of C. Kendall and F. Wallis, Bede: On the Nature of Things and on Times (Liverpool: Liverpool University Press, 2010), in The Medieval Review: https://scholarworks.iu.edu/journals/index.php/tmr/article/view/17613, accessed 13 August 2020.

${ }^{30}$ Cummian, Epistola lines 208-220 (ed. and trans. M. Walsh and D. Ó Cróinín, Cummian's Letter De controversia paschali and the De ratione conputandi [Toronto: Pontifical Institute of Mediaeval Studies, 1988], pp. 84-87).
} 
days -1 day called saltus lunae: $19 \times 6 \times 30+19 \times 6 \times 29+43 / 4+7 \times 30-1=69393 / 4$ days). That is to say that after 19 years, the lunar age of any given Julian calendar date returns to its initial value (e.g., the lunar age on 1 January was luna 5 in AD 700 and returned to this value only in AD 719, 738, etc.). Thus, for a full understanding of the underlying theory, the (solar) Julian calendar and the 19-year lunar cycle needed to be understood. The 19-year lunar cycle posed the biggest challenge here, as the only texts available detailing its constructions were Dionysius's faulty and Proterius's incomplete descriptions. ${ }^{31}$

For the Julian calendar, the authoritative text was Macrobius's Saturnalia, probably composed in the $A D$ 430s or shortly thereafter (i.e. roughly contemporary with Polemius Silvius' calendar). The passages dealing with the Julian calendar (Sat.1.12.2-1.15.20) circulated independently of the main text in a recension called Disputatio Chori et Praetextati. ${ }^{32}$ It was an integral part of the (loosely defined) corpus of computistical texts that reached Ireland before Cummian's days in the AD 630s. ${ }^{33}$ The Disputatio outlines the genesis of the Julian calendar, as perceived by Macrobius: Romulus, the founder of Rome, had designed a calendar of 10 months and 304 days. This calendar is important because it foreshadowed the Julian calendar of seven centuries later. The 10 months were labeled March, April, May, June, Quintilis, Sextilis, September, October, November, December. Of these, April, June, Sextilis (=August), September, November, and December consisted of 30, March, May, Quintilis (= July), and October of 31 days. ${ }^{34}$ Romulus' calendar was reformed by his successor, Numa Pompilius, who added 50 days, resulting in a 354-day year in line with Greek lunar theory. In this process, he introduced two new months (January and February), and reshuffled the number of days per months. March, May, Quintilis (= July), and October remained unaltered at 31 days, while January and February consisted of 28, April, June, Sextilis (=August), September, November, and December of 29 days. In preference for odd numbers, Numa finally added one more day to this year (for a total of 355 days), to the month of January (now of 29 days). ${ }^{35}$ The final reform then happened in the first century BC under Gaius Caesar and his scriba Marcus Flavius: Following Egyptian custom of computing the length of the year on the basis of the sun's course through the zodiac rather than on the lunar phases, Caesar added $101 / 4$ days to Numa's 355. Again, March, May, Quintilis (= July), and October remained unaltered at 31 days, but January, Sextilis (= August), and December were upgraded to the same number, while one day was added to April, June, September, and November for a total of 30 each. The quarter day accumulated to a full day in four years, to be placed before

\footnotetext{
${ }^{31}$ The computistica of Dionysius Exiguus are edited by B. Krusch, 'Studien zur christlich-mittelalterlichen Chronologie: die Entstehung unserer heutigen Zeitrechnung', Abhandlungen der Preußischen Akademie der Wissenschaften Jahrgang 1937, phil.-hist. Klasse 8 (1938), pp. 59-86; for Dionysius' problematic description of the 19-year cycle, see his Epistola ad Bonifatium et Bonum (Krusch, 'Studien', p. 83). Paschasinus' Epistola ad Papam Leonem is edited by B. Krusch, Studien zur christlich-mittelalterlichen Chronologie: der 84jährige Ostercyclus und seine Quellen (Leipzig: Veit, 1880), pp. 245-50: here chapter 1, p. 248. Cf. Warntjes, 'Cradle', pp. 50-51, 65-66.

32 The editio princeps of these excerpts (with translation and commentary) by L. Holford-Strevens has just appeared in print: The Disputatio Chori et Praetextati: the Roman calendar for beginners (Turnhout: Brepols, 2019). The most comprehensive studies before this edition are the transcript of these excerpts from the famous codex Padua BA I 27, 66r-71v by M.J. Carton, Three Unstudied Manuscripts of Macrobius' Saturnalia, (Ph.D. thesis, St. Louis, 1966), pp. 161-203; and A. Arweiler, 'Zu Text und Überlieferung einer gekürzten Fassung von Macrobius Saturnalia I,12,2-I,15,20', Zeitschrift für Papyrologie und Epigraphik 131 (2000), pp. 4557 , who, unfortunately, shows limited awareness of key literature on this text and therefore misses crucial manuscript witnesses. The literature on the Disputatio is conveniently listed in Warntjes, Munich Computus, p. LXVII. I thank Leofranc Holford-Strevens for granting me access to his edition of the Disputatio before publication, and for providing me with a copy of the relevant pages in Carton's study.

${ }^{33}$ See n. 30 above. Whether these texts arrived in Ireland as a corpus, or were there assembles as such, remains a matter of debate.

${ }^{34}$ Disputatio Chori et Praetextati ch. 1, 10 (Holford-Strevens, Roman Calendar for Beginners, pp. 52-55, 64-67).

${ }^{35}$ Disputatio Chori et Praetextati ch. 11-12 (Holford-Strevens, Roman Calendar for Beginners, pp. 66-69).
} 
the fifth last day of February (sextus dies ante Kalendas Martias). Finally, Quintilis was renamed to July in honour of Ceasar, Sextilis was turned into August in honour of the Emperor Augustus. ${ }^{36}$

Table 2: The development of the number of days of the Roman calendar months in three stages, according to Macrobius. The four months that remained unaltered are highlighted.

\begin{tabular}{|l|l|l|l|}
\hline & Romulus & Numa & Caesar \\
\hline January & - & 29 & 31 \\
\hline February & - & 28 & 28 \\
\hline March & 31 & 31 & 31 \\
\hline April & 30 & 29 & 30 \\
\hline May & 31 & 31 & 31 \\
\hline June & 30 & 29 & 30 \\
\hline Quintilis (= July) & 31 & 31 & 31 \\
\hline Sextilis (= August) & 30 & 29 & 31 \\
\hline September & 30 & 29 & 30 \\
\hline October & 31 & 31 & 31 \\
\hline November & 30 & 29 & 30 \\
\hline December & 30 & 29 & 31 \\
\hline
\end{tabular}

Macrobius was also explicit about the structure of each month. Right at the beginning of the Disputatio, when discussing Romulus' calendar, it is argued that hodie ('today')

a) March, May, Quintilis (= July), October have the Nones on the seventh day of the month,

b) all others (a statement that includes January and February, which did not exist in Romulus' framework, but at the time of the author-hodie) have the Nones on the fifth day of the month. ${ }^{37}$

At the end of the text, Macrobius lets Praetextatus argue that the Ides fall on the ninth day after the Nones in every month. ${ }^{38}$

This leaves the number of calends after the Ides for each month. Macrobius did not really have to be explicit about these, since the place of the Nones (either on the fifth or the seventh day) in the respective month, followed by the Ides nine days later (i.e. either on the $13^{\text {th }}$ or $15^{\text {th }}$ day of the month), leaves a clearly defined number of days, depending on the total number of days of the respective month, which Macrobius had explicitly mentioned earlier in his text. But these numbers could also more directly be reconstructed from the Disputatio: At the beginning of the text, Macrobius outlines that the months with the Nones on the seventh day (March, May, Quintilis (= July), October) have 17 calends after the Ides, and these months remained unaffected by the later reforms. ${ }^{39}$ Later on, it is argued that all months to which Caesar added days originally had 17 calends

\footnotetext{
${ }^{36}$ Disputatio Chori et Praetextati ch. 17-18 (Holford-Strevens, Roman Calendar for Beginners, pp. 78-83).

37 Disputatio Chori et Praetextati ch. 1 (Holford-Strevens, Roman Calendar for Beginners, pp. 88-91).

${ }^{38}$ Disputatio Chori et Praetextati ch. 23 (Holford-Strevens, Roman Calendar for Beginners, pp. 54-55).

${ }^{39}$ Disputatio Chori et Praetextati ch. 1 with 18 (Holford-Strevens, Roman Calendar for Beginners, pp. 54-55, 8083).
} 
after the Ides, but this changed to 18 calends for months to which Caesar added one day (April, June, September, November), to 19 calends for months to which Caesar added two day (January, August, December). ${ }^{40}$

The Disputatio Chori et Praetextati is a good example of how patchy the information available to seventh-century Irish monks was, both for solar and especially lunar theory. The data needed to get extracted, reconstructed, systematize, and added to. This endeavour led to the invention of a new genre of text, the computistical textbook. Three such textbooks survive in full from pre-Bedan Ireland. ${ }^{41}$ Of these, only one is datable, the so-called Munich Computus of AD 718/9. Internal evidence suggests that the Computus Einsidlensis was composed slightly earlier, and De ratione conputandi, the most sophisticated of the three outshining Bede's rather wordy work in precision and clarity, slightly later. ${ }^{42}$ This order is confirmed by their discussions of the Julian calendar. The principle structure is the same in all three texts: ${ }^{43}$

1) definition of the terms Kalendae, Nonae, Idus, principally based on the Disputatio Chori;

2) classification of the months in 2 groups according to the number of days before the Nones (4 or 6 when referring to the nones proper, 5 and 7 when referring to the total number of days before the Nones, including the Calends), in 4 groups according to the number of calends after the Ides $(19,18,17,16)$;

3) concordances of the months, according to the total number of days, the number of days before the Nones, and the number of calends after the Ides:

a. January, August, December: 31, 4 (or 5), 19

b. March, May, July, October: 31, 6 (or 7), 17

c. April, June, September, November: 30, 4 (or 5), 18

d. February: 28, 4 (or 5), 16;

4) illustration of the structure of individual months.

This is followed by weekday calculations within this Julian calendar structure.

The earliest two of these three textbooks, the Computus Einsidlensis and the Munich Computus, include a limited vernacular element in the otherwise Latin text. Evidently, these texts were written by Irish authors for an Irish audience. The vernacular was often introduced when explaining

${ }^{40}$ Disputatio Chori et Praetextati ch. 18 (Holford-Strevens, Roman Calendar for Beginners, pp. 82-83).

${ }^{41}$ There is a good chance to find more pre-Bedan Irish computistical texbooks in the thousands of medieval computistical manuscripts, in full or in parts. Fragments of what appears to have been a full textbook have survived in Harvard HL Typ 613, 7r-v; Regensburg SB Frag. 1ar-v, 1dr-1ev. The Irish computistica incorporated in the scientific encyclopedia preserved in Vatican BAV Reg. Lat. 123 (Ripoll, saec. XI) may also stem from a full textbook; see J. Bisagni, 'The newly-discovered Irish and Breton computistica in Città del Vaticano, BAV, MS Reg. Lat. 123', Peritia 28 (2017), pp. 13-34.

42 The Munich Computus is edited and translated in I. Warntjes, Munich Computus: Text and Translation. Irish Computistics between Isidore of Seville and the Venerable Bede and Its Reception in Carolingian Times (Stuttgart: Franz Steiner Verlag, 2010); De ratione conputandi is edited by Dáibhí Ó Cróinín in Walsh and Ó Cróinín, Cummian's Letter, pp. 99-213; an editio princeps of the Computus Einsidlensis by Tobit Loevenich (Trinity College Dublin) is in preparation; the sole manuscript of this text is Einsiedeln SB 321 (647), pp. 82-125 (Lake Constance region?, c.AD 874-892), accessible online at: https://www.ecodices.unifr.ch/de/list/one/sbe/0321, accessed 13 August 2020; for this text, see especially J. Bisagni and I. Warntjes, 'The Early Old Irish material in the newly discovered Computus Einsidlensis (c.AD 700)', Ériu 58 (2008), pp. 77-105. For the chronological order of these three texts, see especially Warntjes, Munich Computus, pp. CXXXIII-CLII, CXCl-CCl.

${ }^{43}$ Computus Einsidlensis (Einsiedeln SB 321 (647), pp. 94-96); Munich Computus ch. 24-28 (Warntjes, Munich Computus, pp. 70-81; in slightly different order); De ratione conputandi ch. 30-32 (Walsh and Ó Cróinín, Cummian's Letter, pp. 142-44). 
particularly complex concepts, which had never before been expressed in Latin. At least these authors had no exemplar to work from when they formulated these ideas. Interestingly, Old Irish was used in two of the four passages outlined above, which clearly indicates that both the available sources and the structure of the Julian calendar with its counter-intuitive backward count from the marker days Calends, Nones, and Ides, was considered a challenge by the receiving society. The author of the Munich Computus reverts to his native tongue when explaining the concordances of the months (item 3), probably because he was used to express this in Irish in the classroom. ${ }^{44}$ More impressive is the Einsiedeln computist's paralleling in two columns of Old Irish ordinal numbers with the first 13 Julian calendar dates of January (item 4). The vernacular here serves two purposes: 1) clearly separating the two columns; 2 ) making sure that the reader / student fully understands how the Julian calendar's backward count translates into the continuous forward count that Irish monks would have been used to. ${ }^{45}$

[Figure 3.2: Einsiedeln SB 321 (647), p. 97]

$\begin{array}{lll}\begin{array}{l}\text { Old Irish } \\ \text { oin }\end{array} & \begin{array}{l}\text { translation } \\ \text { the first }\end{array} & \begin{array}{l}\text { Julian calendar dates } \\ \text { Kalendae }\end{array} \\ \text { ailiu } & \text { the second } & \text { IIII Nonas } \\ \text { tres } & \text { the third } & \text { III Nonas } \\ \text { cethirmat } & \text { the fourth } & \text { II Nonas } \\ \text { coicet } & \text { the fifth } & \text { Nonae } \\ \text { sesset } & \text { the sixth } & \text { VIII Idus } \\ \text { sechtmet } & \text { the seventh } & \text { VII Idus } \\ \text { octmet } & \text { the eighth } & \text { VI Idus } \\ \text { nomet } & \text { the ninth } & \text { V Idus } \\ \text { decmed } & \text { the tenth } & \text { IIII Idus } \\ \text { oindeac } & \text { the eleventh } & \text { III Idus } \\ \text { ailiu deac } & \text { the twelfth } & \text { II Idus } \\ \text { tres deac } & \text { the thirteenth } & \text { Idus }\end{array}$

At the same time as the Irish computistical textbooks, around $A D 700$, the information for the construction of a calendar grid was also systematized on the Continent. One of the earliest stages may be represented in MS Paris BnF Lat. $14086 .{ }^{46}$ The text reads in full:

Ianuarius dies XXXI: [Kalendas] lanuarias, IIII Nonas, VIII Idus, XVIIII kalendas Februarii

Februarius dies XXVIII: [Kalendas] Februarias, IIII Nonas, VIII Idus,, XVI Kalendas Martias

Martius dies XXXI: Kalendas Martias, VI Nonas, VIII Idus, XVIII Kalendas Aprilii

Aprilis dies XXX: Kalendas Aprilii, IIII Nonas, VIII Idus, XVIII Kalendas Madias (sic)

\footnotetext{
${ }^{44}$ Munich Computus ch. 28 (Warntjes, Munich Computus, pp. 80-81). See J. Bisagni and I. Warntjes, 'Latin and Old Irish in the Munich Computus: a reassessment and further evidence', Ériu 57 (2007), pp. 1-33, esp. 17-28.

${ }^{45}$ Einsiedeln SB 321 (647), p. 97. See Bisagni and Warntjes, 'Early Old Irish material', pp. 96-102.

${ }^{46}$ Paris BnF Lat. 14086, 1v-2r (c.AD 700, Langres from a Luxeuil exemplar?; accessible online at: https://gallica.bnf.fr/ark:/12148/btv1b105110031.r=14086?rk=21459;2, accessed 13 August 2020). Cf. especially F. Piper, Karls des Grossen Kalendarium und Ostertafel (Berlin: Decker, 1858), pp. 60-67; P. Salmon, 'Le martyrologe-calendrier conserve dans le manuscript latin 14086 de Paris et ses origins', Revue Bénédictine 56 (1945-46), pp. 42-57; B. Krusch, 'Chronologisches aus Handschriften', Neues Archiv der Gesellschaft für ältere deutsche Geschichtskunde 10 (1885), pp. 81-94, esp. 91-93; Borst, Kalenderreform, pp. 213-14.
} 
Maius dies XXXI: Kalendas Maias, VI Nonas, VIII Idus, XVII Kalendas Iunias

Iunius dies XXX: Kalendas Iunias, IIII Nonas, VIII Idus, XVIII Kalendas Iulias

Iulius dies XXXI: Kalendas Iulias, VI Nonas, VIII Idus, XVII Kalendas Agustas

Agustus dies XXXI: Kalendas Agustas, IIII Nonas, VIII Idus, XVIIII Kalendas Septembris

September dies XXX: [Kalendas] Septembris, IIII Nonas, VIII Idus, XVIII Kalendas Octobris

October dies XXXI: [Kalendas] Octobris, VI Nonas, VIII Idus, XVII Kalendas Novembris

November dies XXX: [Kalendas] Novembris, IIII Nonas, VIII Idus, XVIII Kalendas Decembris

December dies XXXI: Kalendas Decembris, III Nonas, VIIII Idus, XVIIII Kalendas Ianuarias

A more compressed and systematized version of this passage can be found later in the eighth century: ${ }^{47}$

[Figure 3.3: St Gall SB 225, p. 120]

Ianuarius, Augustus et Decembris: dies XXXI, IIII Nonas, VIII Idus, XVIIII Kalendas.

Martius, Maius, Iulius e[t] Octobris: dies XXXI, VI Nonas, VIII Idus, XVII Kalendas.

Aprilis, Iunius, Septembris et Novembris: dies XXX, IIII Nonas, VIII Idus, XVIII Kalendas.

Februarius: dies XXVIII, IIII Nonas, VIII Idus, XVI Kalendas.

By AD 760 at the latest, this information was turned into a standardized wording that followed the Irish precursors. ${ }^{48}$ It remained extremely popular throughout the entire early Middle Ages, as it features in virtually every computistical manuscript that survives.

With this information at hand, it certainly was no problem, in the seventh century, to compose the 365-entry grid divided into 12 months needed for producing a calendar. How this grid was then populated with additional data was obviously up to the composer. Of the three categories outlined by Borst to define an early medieval calendar, the first, liturgical and martyrological entries, appeared, according to the Christian purpose the calendar had to serve, the most essential to

\footnotetext{
${ }^{47}$ St Gall SB 225, p. 120 (AD 773?, St Gall; accessible online at: https://www.ecodices.unifr.ch/de/list/one/csg/0225). For the computistical section of this codex, see especially K. Springsfeld, 'Eine Beschreibung der Handschrift St. Gallen, Stiftsbibliothek, 225', in Warntjes and Ó Cróinín (eds), Computus and Its Cultural Context, pp. 204-37.

${ }^{48}$ The first datable text that contains this systematization is Lect. comp. ch. 19 of AD 760, edited by A. Borst, Schriften zur Komputistik im Frankenreich von 721 bis 818, 3 vols (Hannover: Hahn, 2006), p. 552.
} 
include. The inclusion of computistical material was at least very intuitive, as the calendar grid provided excellent visualization for the placements of, e.g., the bissextile day and especially the embolisms, but obviously also, and more importantly, for the Julian calendar limits for Easter Sunday and for the related beginning of Lent.

A word needs to be said here about the computistical material found in early medieval calendars. First, all medieval calendars are Dionysiac. In Late Antiquity and the early Middle Ages, various competing methods of calculating Easter existed. ${ }^{49}$ By AD 800, the Alexandrian method as translated into Latin by Dionysius Exiguus was unanimously followed throughout Christendom (and remained so until the Gregorian calendar reform of AD 1582). Rome accepted it by the AD 640s or 650s, AngloSaxon England in the second half of the seventh century, Ireland from the AD 680s in a slow process ending in $A D 716$, Pictland in AD 710, Wales in AD 768. ${ }^{50}$ In Francia, it was introduced through Willibrord's mission of AD 689 and by AD 800 all parts of Charlemagne's Empire seem to have accepted it, preplacing Dionysius's main rival, Victorius of Aquitaine's Easter table composed in AD 457 and officially sanctioned by the Frankish Church at the Council of Orleans in AD 541. Some calendars display Victorian data. In all of these instances, however, the favoured Easter reckoning is, without exception, the Dionysiac one, the Victorian material is only introduced as comparative information. ${ }^{51}$ As far as can be assessed from the surviving witnesses, there is no such thing as a Victorian calendar. The medieval calendar tradition is intrinsically connected to Dionysius.

But Dionysius, in his own writings, remained silent about crucial information. In fact, he was a rather limited computist himself. Crucially, he gave no indication of the placements of the embolisms and the saltus lunae..$^{52}$ With no authoritative account on these questions, early medieval computists designed their own regional customs. ${ }^{53}$ In this sense, the Bedan placements of the embolisms was just one of many options. Bede's writings became standard by the early ninth century. Non-Bedan placements of the embolisms in particular, as they are sometimes found in early medieval calendars, therefore appear to indicate an older computistical stratum.

\footnotetext{
${ }^{49}$ The best study of these reckonings, though outdated, is E. Schwartz, 'Christliche und jüdische Ostertafeln', Abhandlungen der königlichen Gesellschaft der Wissenschaften zu Göttingen, philologisch-historische Klasse, Band 8, Nr. 6 (Berlin: Weidmannsche Buchhandlung, 1905). See now A.A. Mosshammer, Easter Computus and the Origins of the Christian Era (Oxford: Oxford University Press, 2008), pp. 3-316; S. Stern, Calendars in Antiquity: Empires, States, and Societies (Oxford: Oxford University Press, 2012), pp. 380-430; and the excellent survey by L. Holford-Strevens, 'Paschal lunar calendars up to Bede', Peritia 20 (2008), pp. 165-208. ${ }^{50} \mathrm{~A}$ guide to further literature on these processes is provided by Warntjes, Munich Computus, pp. XXXV-XLI. ${ }^{51}$ Englisch, Zeiterfassung, pp. 28-40, argues that the calendar in Cologne DB 83-II, 72v-76r (Cologne, AD 805) belongs to a stage when the Dionysiac and the Victorian reckonings were compared closely in Francia, reflected in the fact that, in this calendar, details of both methods of calculation Easter can be found side-byside without commitment for either. This is not the case, the Cologne calendar is indisputably Dionysiac. Englisch's argument hinges on the embolismic lunar months recorded in this calendar, which she believes are Victorian. They are not (note that Englisch had to posit 'modification' of the Victorian system, a shift of the saltus; all of this hypothetical construction is not necessary, the embolisms are perfectly Dionysiac, just not Bedan). Dionysius had not stipulated dates for the intercalation of the embolismic lunar months. This led to varying customs in the Latin West in the seventh and eighth century (all within the Dionyisac framework), of which Bede was just one of many. Because of her lack of engagement with the computistical literature of the early eighth century other than Bede, Englisch does not entertain the possibility that the embolismic lunar months in the Cologne calendar reflect non-Bedan Dionysiac practice, which is exactly what they do. The only Victorian information in the Cologne calendar is the reference to the saltus on 17 November, which contradicts Englisch's supposition that the author of the Cologne calendar worked from a 'modification' of the Victorian reckoning that placed the saltus elsewhere.

${ }^{52} \mathrm{Cf}$. the previous note and Warntjes, Munich Computus, pp. XLV-XLVI.

${ }^{53}$ The two regions that developed the most distinctive features are Ireland and Visigothic Spain. For Ireland, see Warntjes, Munich Computus, pp. LXIX-LXIII, CXXXIII-CLII, CLIX-CLXVIII; idem, 'Irische Komputistik', pp. 1621. A full-scale study of Visigothic computistica is currently prepared by Alden Mosshammer and myself.
} 
The last of Borst's three criteria, astronomical entries, depended heavily on Pliny in the early medieval calendar tradition. At what date the Pliny reception set in in Ireland is debatable. Certainly, the three Irish computistical textbooks introduced above did not know Pliny. First traces may be found in the Irish eclipse prediction of AD $754 .{ }^{54}$ More generally, the Irish computistical textbooks are almost completely silent about astronomical phenomena. If, therefore, a calendar was produced in Ireland in the second half of the seventh century or the first half of the eighth, one would expect the first two of Borst's characteristics (liturgical / martyrological and computistical entries), but not necessarily astronomical phenomena.

What is important here, though, is the realisation that by the mid-seventh century, certainly Visigothic Spain and Ireland had all essentials for the creation of substantial calendars which only lacked the third of Borst's characteristics.

\section{The Zürich (Nivelles) calendar}

That a calendar could be created from the information available in the seventh century without the need for a Roman model, can best be illustrated by means of an indicative example. In order to understand the early history of medieval calendars, it is essential to closely study the earliest exponents of this genre. In eighth-century Latin manuscripts, the following calendars can be found: ${ }^{55}$

\footnotetext{
${ }^{54}$ The Irish author of the eclipse prediction of $A D 754$, when explaining the reasons why a solar eclipse may not be visible to the observer, uses the exact same arguments, in the exact same order, as Pliny in Naturalis Historia ch. II 10, II 71. For this text, see I. Warntjes, 'An Irish eclipse prediction of AD 754: the earliest in the Latin West', Peritia 24-25 (2013-14), pp. 108-115; and C.P.E. Nothaft, Walcher of Malvern: De lunationibus and De dracone (Turnhout: Brepols, 2017), p. 39, on the relevant passage. More generally on the reception of Pliny in early medieval Ireland, see A. Borst, Das Buch der Naturgeschichte: Plinius und seine Leser im Zeitalter des Pergaments (Heidelberg: Universitätsverlag C. Winter, 1994), pp. 95-97; the only earlier trace of Pliny in Ireland appears to be the use of the unusual Plinian term mentagra by Cummian in AD 634 and in Laidcen's Lorica of shortly thereafter.

${ }^{55}$ This is not to say that eighth-century calendars do not survive in later manuscripts. Good examples are: Borst's key witness, the Reichskalender of AD 789, which survives in a Prüm manuscript of $c . A D 840$ (Berlin SBPK Phillipps 1869, 1r-11v); the calendar in Trento MP 1590, 204r-217v (northern Italy, c.AD 835), which can be dated internally to AD 772 (though Borst, in my opinion unjustified, doubts such an early date;

Reichskalender, p. 201). Note also that AD 800 is obviously a rather artificial cut-off point, though one supported by palaeographical practice (Lowe's Codices Latini Antiquiores operate with AD 800 as the end date of the catalogue); the first two decades of the ninth-century, i.e. the 20 years immediately after the cut-off point chosen here, saw the composition (or copying) of numerous calendars (in the order in which they appear in Borst, Kalenderreform, XVIII-XXVI, with c7A added from Borst, Streit, pp. 137-39): Vatican BAV Pal. lat. 1449, 3r-8v (Lorsch, c.AD 810) - A2; Vatican BAV Pal. lat. 1448, 6r-11v (Trier, AD 810) - A3; Cologne DB 83-II, 72v-76r (Cologne, AD 805) - A4; Cologne DB 103, 3r-8v (Cologne, AD 810-19) - A5; Vatican BAV Pal. lat. 1447, 11v-17v (Mainz, AD 808-13) - a1; Munich BSB Clm 14456, 48r-53v (Regensburg, AD 810-23) - a2; Berlin SBPK Phillipps 1831, 1r-6r (Verona, AD 800-10) - B1; Florence BML Plut.36.39, 1r-6v (Verona, AD 816/7) - B3; Rome BNC 641, 76r-81v (Montecassino, AD 811-2) - B4; Milan BA H 150 inf., 55r-56v (Bobbio, c.AD 810) - b1; Berlin SBPK Phillipps 1831, 135r-137v (Verona, AD 818/9) - b2; Rome BNC 26, 3r-8v (Lyon, AD 814-6) - C1; Trier SB 592, 140r-146r (central or eastern France, c.AD 820) - c2a; Paris BnF nal 1586, 119r-120v (Tours, saec. IX ${ }^{\text {ex }}$ ); Madrid BN 3307, 5r-6v, 79r-80v (Murbach, c.AD 820) - D1; Munich BSB Clm 210, 7v-15v (Salzburg, AD 810-8) - E1; Vienna ÖNB 387, 7v-15v (Salzburg, AD 810-30) - E2.
} 
Anglo-Saxon

Paris BnF Lat. 10837: this is the famous Willibrord calendar discussed above.

IImmuenster Kalenderfragment (Munich HAS Raritätenselekt 108, now lost): This is a one-folio binding fragment in Anglo-Saxon script, covering 3-24 May and 4-24 June only. ${ }^{56}$ On these 43 lines, no less than 5 Anglo-Saxons are recorded by the original hand (the Northumbrian kings Ecgfrith and Osric, Ecgfrith's queen ÆEthelthryth, Bishop Eadberht of Lindisfarne and Archbishop of York John of Beverley). All these entries point to Northumbria. Traditionally, Northumbria consisted of two parts, the northern Bernicia, and the southern Deira. 4 of the 5 Northumbrians recorded belong to a Bernician context (only John of Beverley belongs rather to a Deiran context), as does the mention of the Irish saint Columba of Iona, ${ }^{57}$ from where Bernicia received Christianity. Thus, a Bernician origin of the calendar would seem most likely, but Mechthild Gretsch has recently argued for Continental composition (in the circle of Boniface) on linguistic grounds. ${ }^{58}$ Of the entries that have survives, the latest is that of Osric of Northumbria (+729), while the earliest addition in a later hand is that of Boniface (†754), pointing to AD $729 \times 754$ as the time of writing. No particular interest in computistical and astronomical events is discernible, though it should be noted that May and June do not usually abound with computistical data. ${ }^{59}$ The fragment is now lost, 'last seen in 1939'. ${ }^{60}$

Walderdorffsches Kalenderfragment: The library of the count of Walderdorff at Castle Kautzenstein near Regensburg houses the fragment of a calendar in Anglo-Saxon script. ${ }^{61}$ Of the same manuscript,

\footnotetext{
${ }^{56}$ This calendars was transcribed by R. Bauerreiß, 'Ein angelsächsisches Kalendarfragment des bayrischen Hauptstaatsarchivs in München', Studien und Mitteilungen zur Geschichte des Benediktiner-Ordens und seiner Zweige 51 (1933), pp. 177-82, esp. 178-79; this transcription was copied by K. Gamber, Das Bonifatius-

Sakramentar und weitere frühe Liturgiebücher aus Regensburg (Regensburg: Friedrich Pustet, 1975), pp. 49-52; only the entries by the original hand were copied from Bauerreiß's transcription by P. Grosjean, 'Un fragment d'obituaire Anglo-Saxon du VIII siècle naguère conservé à Munich', Analecta Bollandiana 79 (1961), pp. 32045, esp. 322.

${ }^{57}$ Columba's death is recorded two days too early; for discussion of this misdating, see Grosjean, 'Fragment', pp. 328-31, 340.

${ }^{58}$ M. Gretsch, 'Ethelthryth of Ely in a lost calendar from Munich', Anglo-Saxon England 35 (2006), pp. 159-77, esp. 170-73.

59 Computistical elements are the column of synodic lunar letters and the Bedan beginning of summer on 9 May (the CX days given here for the summer period is clearly a scribal error for XC, not given by Bede, De temporum ratione 35, but correctly recorded in later calendars; cf. Borst, Reichskalender, pp. 871, 873-74; that this error was introduced by the original scribe and not by Bauerreiß in his transcription is evident from the facsimile in CLA 9 facing p. 3).

${ }^{60}$ CLA vol. 9, p. 3 (no. 1236).

${ }^{61}$ This calendar fragment was first edited by P. Siffrin, 'Das Walderdorffer Kalenderfragment saec. VIII und die Blätter eines Sakramentars aus Regensburg', Ephemerides Liturgicae 47 (1933), pp. 201-24, esp. 204-09; a more accessible edition with full facsimile is provided by Gamber, Bonifatius-Sakramentar, pp. 53-59.
} 
two more fragments survive, both preserving excerpts of the same sacramentary. ${ }^{62}$ According to Bischoff, the script is Northumbrian. ${ }^{63}$ Since the early $20^{\text {th }}$ century, a narrative has been constructed that it was Boniface who donated the sacramentary with calendar to the diocese of Regensburg at its foundation in AD 739. ${ }^{64}$ The earliest datable addition to the calendar is that of Duke Theudebald, who died in AD 719, presumably in Regensburg. ${ }^{65}$ Place of rule, death, and burial may be the reason why Theobald's name was added to the calendar some 20 years after his death, after Boniface, in the common narrative, had given the codex to the newly founded bishopric. But I see no reason why this entry could not have been written earlier, closer to the duke's death. Certainly Boniface was active in Bavaria from at least AD 724, and there is no certainty that this calendar was originally owned by him. Of the original entries, the youngest layer points to Anglo-Saxon England, with the commemoration of Bishop Paulinus of York ( +644 ) on 14 October and Archbishop Honorius of Canterbury ( +653 ) on 30 September. Paulinus seems to be the more indicative of these two figures, as he was the most influential person in Christianising southern Northumbria, the kingdom of Deira. Unfortunately, only the months July to October survive of this calendar. But from what is preserved, nothing speaks against the possibility that this calendar was originally composed in Deira in the last few decades of the seventh century, earlier than or contemporary to Willibrord's calendar (and then later copied in the early eight century to be sent to the Continent). Maybe the sacramentary and calendar was given to Boniface by Willibrord when Boniface, after 3 years with his Northumbrian mentor, left in AD 721 to embark on his own missionary expedition. Like Willibrord's calendar, the Walderdorffer fragment contains the sequence of synodic lunar letters in the left-hand column. Additionally, it lists the Isidorian beginning of autumn, and the 'Latin' autum equinox. Since the IImmünster calendar already contained Bedan information of which the Walderdorffer fragment is ignorant, I would be inclined to consider Walderdorff older than IImmünster.

Irish

St Gall SB 51, 239-240 (Palimpsest): This manuscript is one of the oldest and most famous Irish Gospel codices that survive on the Continent. Pages 239-240 are a palimpsest, and the original text that was scraped off the vellum to reuse it for the Gospels was, in fact, a calendar. Unfortunately, the deletion was done so thoroughly that hardly anything remains decipherable. But since the

\footnotetext{
${ }^{62}$ Berlin SBPK Lat. Fol. 877; Regensburg BZB Cim. 1. See especially A. Fingernagel, Die illuminierten lat. Handschriften deutscher Provenienz der Staatsbibliothek PK Berlin, 8.-12. Jahrhundert (Wiesbaden: Harrassowitz, 1991), p. 119.

${ }^{63}$ CLA vol. 8, p. 9 (no. 1052); B. Bischoff, Die südostdeutschen Schreibschulen und Bibliotheken in der Karolingerzeit, Teil 1: Die bayerischen Diözesen (3rd ed., Wiesbaden: Harrassowitz, 1974), pp. 183-84, with additions in idem, Die südostdeutschen Schreibschulen und Bibliotheken in der Karolingerzeit, Teil 2: Die vorwiegend österreichischen Diözesen (Wiesbaden: Harrassowitz, 1980), p. 235.

${ }^{64}$ This is the suggestion of Count Hugo of Walderdorff as related by Siffrin, Walderdorffer Kalenderfragment, pp. 212-13, and has often been repeated since. More skeptical is CLA vol. 8, p. 9 (no. 1052); H. Frank, 'Die Briefe des heiligen Bonifatius und das von ihm benutzte Sakramentar', in Sankt Bonifatius: Gedenkausgabe zum zwölfhundertsten Todestag (Fulda: Parzeller, 1954), pp. 58-93, esp. 76-79.

${ }^{65}$ For the hand of this addition see Bischoff, Die südostdeutschen Schreibschulen 1, p. 184.
} 
Gospels were written in Ireland in a hand of the late eighth century, this palimpsest bears witness to the existence of a calendar in Ireland at around the middle of the eighth century. ${ }^{66}$

Zürich ZB Rhen. 30, 166v-169v: This calendar will be discussed in more detail below.

\section{Frankish}

Paris BnF nal 1203, 121v-124r: This famous evangelistary was written by a certain Godescalc in AD 781-83, probably at Worms, as the dedication poem to Charlemagne and his wife Hildegard at the end of the codex suggest. ${ }^{67}$ An evangelistary is a collection of excerpts from the Gospels to be read in mass on sun- and feast days, starting with Christmas and systematically and linearly progressing through the year. Because of this format, it was only appropriate to accompany this text with a calendar and Easter table, here the Dionysiac one for AD 779-816. The pages of this Prachtcodex were purple, the script in gold and black. In the calendar, the martyrological entries and the grid of days were gold, the remaining data black. The latest martyr mentioned is Boniface (†AD 754), but for the seventh century also includes the Irish Kilian of Würzburg. Godescalc did not provide any information relevant for Easter calculation in the calendar proper, probably because of the following Easter table. The data provided was rather conservative, pre-Bedan, with the Isidorian beginnings of the seasons and the 'Latin' spring equinox and summer solstice. It also included the calendar and lunar days for each months, and the weekday sequence in the left-hand margin.

\section{Italian (Montecassino)}

Paris BnF Lat. 7530, 277v-280r: The codex consists of principally grammatical content. Towards the end (fols 276r-290v), a computistical section is inserted, including a Dionysiac Easter table for AD 779-835 and a calendar. Because of this Easter table, which technically comprises three 19-year lunar cycles, the manuscript (and with it the calendar) is dated the first of these cycles, AD 779$797 .{ }^{68}$ The early Beneventan hand points to Montecassino, as does the purview of the calendar with

${ }^{66}$ CLA vol. 7, p. 20 (no. 901); J.F. Kenney, The sources for the early history of Ireland: ecclesiastical (New York: Columbia University Press 1929, repr. Dublin: Four Courts 1997), p. 649 (no. 486), entertains the possibility that this codex was written on the Continent; see now the convenient entry with further literature in D. Ó Corráin, Clavis litterarum Hibernensium: medieval Irish books and texts (c.400-c.1600) (Turnhout: Brepols, 2017), pp. 483-88. For the calendar, see especially Borst, Kalenderreform, p. 194. The manuscript is available online at: https://www.e-codices.unifr.ch/en/csg/0051/239/0/Sequence-258, accessed 14 August 2020.

${ }^{67}$ For the manuscript, calendar, and Easter table, see especially Piper, Karls des Grossen Kalendarium, pp. 8-19 (description of MS, including dating), 19-35 (edition of calendar and Easter table), 36-37 (edition of dedication poem), 38-50 (discussion of calendar). For the calendar in particular, see Borst, Kalenderreform, pp. 199-200 (with further literature). The manuscript is available online at: https://gallica.bnf.fr/ark:/12148/btv1b6000718s, accessed 14 August 2020.

${ }^{68}$ CLA vol. 5, p. 15 (no. 569). For the manuscript, see especially L. Holtz, 'Le Parisinus Latinus 7530, synthese cassinienne des arts libéraux', Studi medievali, 3rd series 16 (1975), pp. 97-152; V. Brown, 'Where have all the grammars gone? The survival of grammatical texts in Beneventan script', in P. de Paolis, M. de Nonno, and L. Holtz (eds), Manuscripts and tradition of grammatical texts from Antiquity to the Renaissance, 2 vols (Cassino: Edizione dell'Università degli Studi di Cassino, 2000), pp. 389-414. For the calendar, see especially E.A. Loew (later Lowe)'s thesis Die ältesten Kalendarien aus Monte Cassino (Munich: Beck, 1908), pp. X, 4-6, 12-34 (edition), 39 (list of abbots), 42, 64, 69-83, Taf. II; G. Morin, 'Les quatre plus anciens calendriers du Monte- 
its 6 entries of abbots of Montecassino. Except for the Isidorian beginning of winter, the astronomica and computistica listed in this calendar are Carolingian standard: solar and lunar days per months, hours of daylight and night-time at the end of each month, entrance of the sun into the zodiac signs, Bedan beginnings of the seasons with calculated length, 'Greek' spring equinox ( $21 \mathrm{March}$ ) but the 'Latin' summer solstice (24 June), Dionysiac start and end date for Easter new moon (8 March - 5 April) and Easter Sunday (22 March - 25 April), seats of the epacts and concurrents.

Cava de' Tirreni BA 2, 70r-72v: The codex Paris BnF Lat. 7530 just discussed was produced principally as a collection of important grammatical texts. At the same time, the monastic community of Montecassino also composed its own, more comprehensive version of Isidore of Seville's Etymologiae. ${ }^{69}$ In book 6 of his 20-volume work, Isidore included a discussion of Easter, which was very limited in scope and soon outdated. The authorities in Montecassino decided to replace Isidore's chapter by an impressive 12 -folios long computistical fomulary. This included a calendar and, like BnF Lat. 7530, a Dionysiac Easter table starting in AD 779, but extending to AD 873 (as Isidore's orginal Easter table also covered 95 years). Again, the Easter table suggest compilation of the manuscript in the period AD 779-797, which can be further narrowed down to AD 779-792 on the basis of one of the calendrical algorithms. The calendar itself is very plain. Compared to the one in BnF Lat. 7530, it adds the alphabetical sequences in the left-hand column for the sidereal and synodic lunar months, but otherwise only records (besides martyrological entries, of course) the Bedan beginnings of the seasons (omitting spring), the range of the Easter new moon (8 March misplaced 4 rather than 5 April), only the lower limit of Easter Sunday ( 22 March; the upper limit, 25 April, was probably not recorded because the upper limit of the Easter new moon was misplaced), and the 'Greek' spring equinox (21 March) but 'Latin' summer solstice (24 June).

If these calendars are to be compared with Irish computistical knowledge towards the end of the seventh century, only one of the calendars listed qualifies, the calendar in Zürich ZB Rh. $30 .{ }^{70} \mathrm{An}$ interest in matters Irish (or even an Irish background) can fairly easily be detected in calendars with a martyrological / liturgical layer, as this would include Irish Saints. The Zürich calendar contains three entries of four Irish Saints:

16 January: Fursa (†c.649) and Foillan (†c.655)

1 February: Brigit (sixth century?)

17 March: Patrick (fifth century)

Of the Zürich calendar, only seven pages have survived. It starts with Jesus' birth on 25 December (the so-called nativity-style dating of the beginning of a year, a feature of pre-Carolingian calendars), breaks off after 10 April, resumes with 28 May, but then finally breaks off with 13 July. This does not allow for a full-scale interpretation of the evidence, but it provides enough insights for an indicative

Cassin (VIII'-IXe siècles)', Revue Bénédictine 25 (1908), pp. 486-97; Borst, Kalenderreform, pp. 196-98. The manuscript is available online at: https://gallica.bnf.fr/ark:/12148/btv1b84900617, accessed 14 August 2020.

${ }^{69}$ CLA vol. 3, p. 3 (no. 284). For the caldendar, see especially Loew, Kalendarien aus Monte Cassino, pp. X, 1-4, 12-36 (edition), 39, 42, 64, 69-83, Taf. I; Morin, 'Les quatre plus anciens calendriers'.

70 The Zürich/Nivelles calendar is edited in A. Hänggi and A. Schönherr, Sacramentarium Rhenaugiense: Handschrift Rh 30 der Zentralbibliothek Zürich (Freiburg i. d. Schweiz: Universitätsverlag, 1970), pp. 294-99; for a short commentary with further literature, see the convenient entry in Borst, Kalenderreform, pp. 194-96. 
study. Concerning the Irish saints listed, it would have been of considerable interest if Columbanus was remembered on 23 November, or Gallus on 16 October. ${ }^{71}$ What is remarkable is the exclusion of Columba on 9 June. ${ }^{72}$ The reason for this may be found in the calendar's veneration for Fursa and Foillan. Bede, and the Vita Fursei that Bede worked from, only provide the most rudimentary outline of Fursa's life: ${ }^{73}$ Fursa was of noble birth, left Ireland (which part of Ireland is not specified) and travelled through the region of the Britons to East Anglia, where he preached the Gospel under King Sigbert. When pagan opposition grew in East Anglia, he left for Francia, where he was gracefully received by the under-aged Neustrian king Clovis II and, more importantly, his mayor of the palace Erchinoald. Erchinoald granted Fursa land to build a monastery in Lagny-sur-Marne, and the mayor of the palace took control of the body at Fursa's death so that its burial in Péronne (thenceforth known as Peronna Scottorum, no doubt also due to frequent visits by Irish pilgrims) would establish a saint's cult.

The Irish entries in the Zürich calendar, therefore, tell a distinct story. The interest in the regiones Scottorum lies in Leinster, where the cult of Brigit flourished in Kildare and where the first record of Patrick, in Cummian's letter of AD 632, can be located. ${ }^{74}$ Cummian wrote to abbot Ségéne of lona to announce that the southern Irish churches would thenceforth follow 'Roman' Easter practices (at this time the system of Victorius of Aquitaine) against the traditional latercus which lona clung to until AD $716 .{ }^{75}$ This explains the exclusion of Columba, with the Columban community considered the principal adversaries in what became to be known as the Insular Easter controversy. ${ }^{76}$ Cummian may well be connected to a circle of scholars in the eastern midlands, in the border territory between Munster and Leinster, ${ }^{77}$ which saw the production of the cosmological work De mirabilibus

\footnotetext{
71 The calendars recording Gallus' death on 16 October are numerous; see Borst, Reichskalender, pp. $1403-04$. Columbanus is mentioned in one early calendar, Trento MP 1590, 216r (here, and only here, labeled abbot of Bobbio), and later principally in the Lake Constance area and northern Italy; see Borst, Reichskalender, pp. $1517,1519-20$.

${ }^{72}$ Columba is commemorated by Willibrord and in the IImmuenster Kalenderfragment (see above near nn. 20 and 56), the early Trento calendar (fol. 210r), and a considerable number of later calendars; see Borst, Reichskalender, pp. 972-73.

${ }^{73}$ Bede, Historia ecclesiastica ch. III 19 (Plummer, Baedae opera historica, vol. 1, pp. 163-68). Bede worked from the Transitus Fursei; the chapters of this work relevant for Fursa's life have been extracted by Bruno Krusch in MGH SS rer. Merov. vol. 4, pp. 434-40; see now also the English translation of the entire Transitus Fursei by O. Rackham, Transitus beati Fursei: a translation of the $8^{\text {th }}$ century manuscript Life of Saint Fursey (Norwich: Fursey Pilgrims, 2001, repr. 2007).

${ }^{74}$ Cummian's Epistola De controversia paschali lines 208-9 (Walsh and Ó Cróinín, Cummian's Letter, pp. 84-85). Cf. H. Zimmer, 'Keltische Kirche in Britannien und Irland', Realencyklopädie für protestantische Theologie und Kirche, 3rd ed., vol. 10 (1901), pp. 204-43, esp. 208, 210, 219; trans. by A. Meyer as The Celtic Church in Britain and Ireland (London: David Nutt, 1902), pp. 9-10, 18-19, 47-49.

${ }^{75}$ For these Easter reckonings, see nn. 25 and 100.

${ }^{76}$ For the Insular Easter controversy, see the pioneering (though outdated) studies by B. Krusch, 'Die Einführung des griechischen Paschalritus im Abendlande', Neues Archiv der Gesellschaft für ältere deutsche Geschichtskunde 9 (1884), pp. 99-169, esp. 141-69; J. Schmid, Die Osterfestberechnung auf den britischen Inseln vom Anfang des vierten bis zum Ende des achten Jahrhunderts (Regensburg: Verlagsanstalt, 1904); L. Gougoud, Christianity in Celtic lands (London: Sheed \& Ward, 1932, repr. Dublin: Institute for Advanced Studies, 1992), pp. 185-201; P. Grosjean, 'Recherches sur les debuts de la controverse pascale chez les Celtes', Analecta Bollandiana 64 (1946), pp. 200-44. More recently, see Corning, The Celtic and Roman traditions; T.M. Charles-Edwards, Early Christian Ireland (Cambridge: Cambridge University Press, 2000), pp. 391-415. The best study is Masako Ohashi's 1999 Nagoya Ph.D. thesis The Impact of the Paschal Controversy: Computus, Exegesis and Church History in Early Britain and Ireland. See now also I. Warntjes, 'Victorius vs Dionysius: the Irish Easter controversy of AD 689', in P. Moran and I. Warntjes (eds), Early Medieval Ireland and Europe: Chronology, Contacts, Scholarship (Turnhout: Brepols, 2015), pp. 33-97.

77 See P. Grosjean, 'Sur quelques exégètes irlandaise du VII' siècle', Sacris Erudiri 7 (1955), pp. 67-98; Ó Cróinín, 'Irish provenance'.
} 
sacrae scripturae in AD $654^{78}$ and through which the loosely-defined Sirmond corpus of computistical texts was transmitted in AD 658. ${ }^{79}$ Also, the lost Victorian computus of AD 689 can be located here ${ }^{80}$ and likewise the three computistical textbooks mentioned above appear to have been produced in such an intellectual environment in the 'Roman' southern half of Ireland ${ }^{81}$ Fursa and Foillan, in the AD 630s, moved to East Anglia presumably from this background. ${ }^{82}$ When they eventually settled in northern-eastern France, connections were maintained between Ireland and their new foundations of Fosse and Langny-sur-Marne, but also Peronna Scotorum and Nivelles, as, e.g., evidenced by the Irish exile of Dagobert II of Neustria (orchestrated by the Austrasian mayor domus Grimoald, the brother of Gertrudis discussed below). ${ }^{83}$

The Frankish entries in the calendar point to the same region within the Frankish kingdoms, while also suggesting a foreign background of the older of its two layers. This older layer consists of the following popular Frankish saints: Genoveva of Paris ( $+c .502 ; 3$ Jan), Hilary of Poitiers ( $+367 / 8 ; 13$ Jan), Remigius of Reims ( + c.533; 13 and 15 Jan), Vedastus of Arras (†c.540; 6 Feb), Germanus of Paris (†576; 28 May), Medardus of Nyon (†c.560; 8 Jun), and Martin of Tours (†c.397; 4 Jul). Of these, the Martin entry suggests original composition outside of what used to be Roman Gaul. It is phrased as if it commemorated Martin's death on this day, though 4 July rather referred to Martin's consecration as bishop and translation of his remains (he died on 8 November). Such a mistake is likely to have happened far removed from Tours, and, in fact, the entry's explicit geographic reference in Gallis may be an indication of composition outside of formerly Roman Gaul. This older layer of Frankish

\footnotetext{
${ }^{78}$ See M. Esposito, 'On the pseudo-Augustinian treatise, De mirabilibus sanctae scripturae, written in Ireland in the year 655', Proceedings of the Royal Irish Academy 35C (1918-20), pp. 189-207, esp. 196-202; Kenney, Sources, pp. 275-77; G. MacGinty, 'The Irish Augustine: De mirabilibus sacrae scripturae', in P. Ní Chatháin and M. Richter (eds), Ireland und die Christenheit: Bibelstudien und mission (Stuttgart: Klett-Cotta, 1987), pp. 7083, esp. 71-79; D. Ó Cróinín, 'Bischoff's Wendepunkte fifty years on', Revue Bénédictine 110 (2000), pp. 20437, esp. 212-20; the literature on this work is conveniently listed in Ó Corráin, Clavis litterarum Hibernensium, pp. 738-41.

79 Ó Cróinín, 'Irish provenance', pp. 177-85.

${ }^{80}$ Warntjes, Munich Computus, pp. CXXIV-CXXVI.

81 Ibid., pp. LIV-LV, LXXVIII-XCVI, CLII, CXCI-CXCII.

${ }^{82}$ For the chronology of Fursa's departure from Ireland, see especially Plummer, Baedae opera, vol. 2, p. 173; For Fursa being potentially connected, intellectually, to the circle of Leinster scholars mentioned above, see Grosjean, 'Sur quelques exégètes', p. 75 n. 2; idem, 'Chronologie de S. Feuillen', Analecta Bollandiana 75 (1957), pp. 379-93, esp. 381-82 (392 for Fursa's departure in the early AD 630s). P. Ó Riain, 'Les Vies de saint Fursy: les sources irlandaises', Revue du nord 68 (1986), pp. 405-13, esp. 405-10; idem, A dictionary of Irish saints (Dublin: Four Courts, 2011), pp. 357-59, argues for an eastern Ulster background of Fursa, which would firmly place him in Ireland's north. From the historical context of Fursa's later life in East Anglia and Francia, there can hardly be any doubt that Fursa followed 'Roman' practices (more specifically the Victorian Easter reckoning) introduced in southern Ireland in the early AD 630s. If Fursa was from the north, he may have belonged to a group of northern clerics favouring southern practice, and self-imposed exile abroad may have been a viable option for such clerics.

${ }^{83}$ For the Irish background to Dagobert's exile, see especially J.-M. Picard, 'Church and politics in the seventh century: the Irish exile of King Dagobert II', in idem (ed.), Ireland and northern France, AD 600-850 (Dublin: Four Courts, 1991), pp. 27-52; D. Ó Cróinín, 'Merovingian politics and insular calligraphy: the historical background to the Book of Durrow and related manuscripts,' in M. Ryan (ed.), Ireland and insular art, A.D. 5001200 (Dublin: Royal Irish Academy, 1987), pp. 40-43. For Lagny, Fosse, Peronne, and Nivelles, see also A. Dierkens, Abbayes et chapitres entre Sambre et Meuse (VIle-XIe siècles): contribution à I'histoire religieuse des campagnes du Haut Moyen Age (Sigmaringen: Jan Thorbecke, 1985), pp. 293-96, 303-14; idem, 'Prolégomènes à une histoire des relations culturelles entre les îles britanniques et le continent pendant le Haut Moyen Age: la diffusion du monachisme dit colombanien ou iro-franc dans quelques monastères de la région parisienne au $\mathrm{VII}^{\mathrm{e}}$ siècle et la politique religieuse de la reine Bathilde', in $\mathrm{H}$. Atsma (ed.), La Neustrie: les pays au nord de la Loire de 650 à 850, 2 vols (Sigmaringen: Jan Thorbecke, 1989), vol. 2, pp. 371-94, esp. 385-88.
} 
Saints, up to c.AD 600, was probably copied directly from a late-sixth-century recension of the Martyrologium Hieronymianum. ${ }^{84}$

The five seventh-century Frankish entries in the Zürich calendar betray a more regional purview. Only one of these four saints, Sulpicius of Bourges ( $+646 / 7 ; 17$ Jan), falls outside of the core region of the remaining entries, north-eastern Neustria. Sulpicius' inclusion can be explained by his active personal network facilitated by Chlothar II's palace school, which, besides Sulpicius, included later bishops in north-eastern France (Audoenus of Rouen, Paulus of Verdun, and others); this, no doubt, helped spreading Sulpicius' cult in this region, as most prominently manifested in his late seventhcentury Vita. ${ }^{85}$ The main area of interest of the compiler of the Zürich calendar is evidenced by the remaining four entries: Aldegundis of Maubeuge ( $+c .690 ; 30$ Jan); Amandus of Maastricht $(+c .680 ; 6$ Feb); translation of Gertrudis of Nivelles (10 Feb); Gertrudis of Nivelles (†659; 17 Mar). The two entries of Gertrudis are the only ones in the calendar with an explicit place reference, which makes composition in Nivelles likely. St Amand and Maubeuge are less than $50 \mathrm{~km}$ from Nivelles, which explains the very early inclusion of Aldegundis and Amandus (Amandus was also instrumental in the foundation of Nivelles). ${ }^{86}$ The latter two are the last datable saints in the calendar, which points to original composition at c.AD 700 or shortly thereafter (Borst suggests c.AD $750^{87}$ ). The script of the manuscript is dated to saec. VIII-IX by Lowe. ${ }^{88}$

Finally, it may be worth stressing that there is not a single Anglo-Saxon entry in this calendar. One may argue that Willibrord's death ( $7 \mathrm{Nov}$ ) was recorded on the lost November page, and that the omission of Boniface ( 5 Jun) was due to this calendar being composed before the latter's death in AD 754. Still, comparable Anglo-Saxon calendars of roughly the same time (Willibrord, Ilmmünster and Walderdorff) record numerous seventh-century, especially Northumbrian, kings and ecclesiasts. ${ }^{89}$ The only entries of the Nivelles calendar that could potential be connected to an Anglo-Saxon milieu are those of Gregory the Great (†604), his death on 12 March and his ordination in Rome on 29 March. Gregory, famously, sent the first missionaries to Anglo-Saxon England, and his cult was well established in Northumbria towards the end of the seventh century. ${ }^{90}$ At the same time, Gregory may also have received some veneration in Ireland, especially among the southern Irish churches. The southern Irish sent a delegation to Rome when the Easter controversy escalated in the late AD

\footnotetext{
${ }^{84}$ The Martyrologium Hieronymianum survives in various recensions, for which see the neat overviews in P. Ó Riain, Feastdays of the saints: a history of Irish martyrologies (Bruxelles: Société des Bollandistes, 2006), pp. 28; and Borst, Kalenderreform, pp. 202-4. The oldest surviving recension precedes Willibrord's calendar in Paris BnF Lat. 10837, 2r-33v. All seven saints of the older Frankish layer in the Zürich/Nivelles calendar can be found in the Martyrologium Hieronymianum (edited by G.B. De Rossi and L. Duchesne in Acta Sanctorum Novembris 2.1 (Brussels: Bollandists, 1894), pp. 1-195, with the relevant entries on pp. 5, 8, 17, 67, 76, 86), though Vedastus only in the Bern codex. The phrase in Gallis in the Martin of Tours entry on 4 July may be a remnant of this source; still, copying this phrase was a deliberate choice that reflects the context of the copyist.

${ }^{85}$ The Vita Sulpicii episcopi Biturigi is edited by B. Krusch in MGH SS rer Merov. vol. 4, pp. 364-80.

${ }^{86}$ For Maubeuge, Nivelles, and Amandus, see especially the studies by A. Dierkens (with further literature): 'Saint Amand et la foundation de l'abbaye de Nivelles', Revue du Nord 69 (1986), pp. 225-35; 'Notes biographiques sur aint Amand, abbé d’Elnone et éphémère éveque de Maastricht ( ${ }^{\dagger}$ peu après 676 )', in $E$. Bozoky (ed.), Saints d'Aquitaine: missionaires et pélerins du haut Moyen Âge (Rennes: Presses Universitaires de Rennes, 2010), pp. 63-80; 'Maubeuge et Nivelles à la fin du VII siècle: note sur deux passages de la Vita sanctae Aldegundae prima (BHL 244)', in C. Depauw et al. (eds), Hainault: la terre et les hommes (Mons: Hannonia, 2016), pp. 23-47.

87 Borst, Kalenderreform, p. 194.

${ }^{88}$ CLA vol. 7, p. 50 (no. 1019).

${ }^{89}$ See see above, near nn. 20 and 56.

90 One of the earliest Saint's Lives composed in Anglo-Saxon England that has survived is the Vita Gregorii of $\mathrm{AD} 704 \times 714$ by a Whitby anonymous. It is edited and translated by B. Colgrave, The earliest Life of Gregory the Great (repr. Cambridge: Cambridge University Press, 1985).
} 
620 s and early $630 \mathrm{~s}^{91}$ This is a clear indication of the acceptance of Rome as the highest authority in spiritual matters. Gregory himself was heavily involved in the Easter question only some 30 years earlier, when he received a rather audacious letter by the Irish abbot Columbanus arguing for the superiority of 'Irish' over 'Roman' / Frankish practices. ${ }^{92}$ No response by Gregory is recorded, but it can easily be imagined that the southern Irish would cherish his memory as a guardian of Roman authority against northern Irish traditionalists in the Easter controversy of the remaining decades of the seventh century.

Thus, the Zürich calendar reveals a seventh-century (southern) Irish background and an early eighthcentury composition in Nivelles with a particularly strong focus on its local monastic network. The Irish or Irish-influenced foundations of Lagny-sur-Marne, Fosse, and Péronne provide the link between Ireland and the Frankish heartland. Nivelles itself boasted an import of scholars from 'regions across the sea' according to the Vita Geretrudis of c.AD 670, which surely included Ireland..$^{93}$ The computistica in the Nivelles calendar, therefore, are quite likely to reflect Irish thought imported to Francia towards the end of the seventh century.

\section{The computistical data of the Zürich (Nivelles) calendar}

[Figures 3.4-5: Zentralbibliothek Zürich, Ms. Rh. 30, fols. 168r-168v: March page]

In fact, a comparison of the computistical data of the Nivelles calendar to the pre-Bedan Irish computistical textbooks leads to an almost perfect match. The only exception is the list of lunar letters in the left hand column.

Table 3: Overview of the computistical entries in the Zürich / Nivelles calendar of c.AD 700 (Zürich ZB Rh. 30,166v-169v). Additionally, the left-hand column of the calendar contains synodic lunar letters, and each month is headed by the number of calendar and lunar days.

\begin{tabular}{|l|l|l|}
\hline 25 Dec & VIII KI lan & Solstitium apud Latinum \\
\hline 9 Jan & V Id Ian & VII hore in diae \\
\hline 24 Jan & VIIII KI Feb & VII(I) hore in die \\
\hline 8 Feb & VI Id Feb & $\begin{array}{l}\text { VIIII hore in diae et terminus initium quadragesimae usque II Idus } \\
\text { Mai- (recte Martii) }\end{array}$ \\
\hline 24 Feb & VI KI Mar & bisextus \\
\hline 8 Mar & VIII Id Mar & Initium primi mensis usque Nonas Aprilis \\
\hline 10 Mar & VI Id Mar & XI hore in diae \\
\hline 21 Mar & XII KI Apr & Equinoctium secundum Grecos et prim<i>us dies saeculi \\
\hline
\end{tabular}

\footnotetext{
${ }^{91}$ Cummian, Epistola lines 259-288 (Walsh and Ó Cróinín, Cummian's Letter, pp. 90-95).

92 Columbanus, Epistula I (ed. and trans. G.S.M. Walker, Sancti Columbani Opera [Dublin: Dublin Institute for Advanced Studies, repr. 1997], pp. 2-13).

${ }^{93}$ Vita Geretrudis ch. 2 (edited by B. Krusch in SS rer. Merov. 2, 457). Transmarinae regiones can only refer to Britain and/or Ireland. Prinz interprets this phrase to refer to Ireland; F. Prinz, Frühes Mönchtum im Frankenreich (2nd ed., Darmstadt: Wissenschaftlich Buchgesellschaft, 1988), pp. 186, 661. Certainly, the calendar under discussion here points solely to Ireland, not Britain.
} 


\begin{tabular}{|l|l|l|}
\hline $22 \mathrm{Mar}$ & XI KI Apr & $\begin{array}{l}\text { Hi incipient epacte et in die terminationis pasce, equinoctium apud } \\
\text { Grecos, usque ad VII Kalendas Maii }\end{array}$ \\
\hline $25 \mathrm{Mar}$ & VIII KI Apr & XII hore in die, equinoctium apud Latinos \\
\hline $1 \mathrm{Apr}$ & KI Apr & Initium secundi mensis \\
\hline 20 June & XII KI lul & Solstitium secundum Egyptios \\
\hline
\end{tabular}

lunar letters

In the left-most column of the Nivelles calendar, there is a list of three successive alphabets (all omitting j; cf. Facsimile 4): the first simply from a to $\mathrm{u}$; the second also from a to $\mathrm{u}$ but with two dots placed to the right of each letter; the third from a to $t$ with two dots placed to the left of each letter (a-u, a:-u:, :a-:t). This amounts to a letter system of a total of 59 items, representing a full and a hollow lunar month of 30 and 29 days respectively. The idea behind this system is to easily identify Julian calendar dates with the same lunar age, i.e. those with the same alphabetic symbol. ${ }^{94}$ The preBedan Irish computistical textbooks do not refer to this system, because they had no interest in tabular oversimplification of data that could easily be calculated by basic calendrical algorithms. Bede explained it in exuberant detail, because his textbook was designed for students who needed lengthy explanations for simple concepts, ${ }^{95}$ this alphabetic system for the stupid among these ('for those who do not know how to calculate', who are 'lazy or bored'). ${ }^{96}$ He provided a table that assigns a specific lunar age to each of these letters for every year of the 19-year cycle (e.g., letter a has luna 9 in year 1 , luna 20 in year 2, luna 1 in year 3, etc.). With this additional table, the exact lunar age of any given Julian calendar date could be inferred from the alphabetic symbol found in the calendar, provided the reader knew which year in the 19-year cycle one lived in. But, as mentioned, the system certainly also had its use without the additional table, indicating Julian calendar dates with the same lunar age. Thus, no calendar necessarily needed an additional table to translate the alphabetic symbols.

It is evident that Bede did not invent this system, either in form of the calendar column or the additional table. Willibrord's calendar already incorporated the alphabetic column, which, in this form, did not occur in the Roman models of 354 and Polemius Silvius. The additional lunar table also appears to be pre-Bedan (Bede himself ascribes its composition to Antiquitas; by the early ninth century it is attributed to Jerome). There certainly is no reason to doubt that this system circulated in the last three decades of the seventh century. ${ }^{97}$ Interestingly, the three alphabets are rather sloppily noted in the Nivelles calendar, omitting most of the punctuation. This suggests that either the author or, more likely, the copyist did not understand the mechanics of the underlying system.

\footnotetext{
${ }^{94}$ See especially T. Sickel, 'Die Lunarbuchstaben in den Kalendarien des Mittelalters', Sitzungsberichte der Akademie der Wissenschaften in Wien, phil.-hist. Klasse, 38 (1862), pp. 153-201, esp. 159-68; Borst, Kalenderreform, pp. 405-11; C.P.E. Nothaft, Scandalous Error: Calendar Reform and Calendrical Astronomy in Medieval Europe (Oxford: Oxford University Press, 2018), pp. 54-55 (with further literature).

95 In the preface to his De temporum ratione (Jones, Bedae opera, p. 175), Bede explicitly states that his brethren urged him to expand on his earlier De temporibus, as they considered that too concise.

${ }^{96}$ Bede, De temporum ratione ch. 23 (Jones, Bedae opera, pp. 224-26): quis computare non potest; quisque deses vel hebes est.

97 See especially C.W. Jones, Bedae Pseudepigrapha: scientific writings falsely attributed to Bede (Ithaca: Cornell University Press, 1939), pp. 65-68; and also Jones, Bedae opera, pp. 358-59; Borst, Kalenderreform, 406-08.
} 
But, to be sure, the author of this calendar would have had no problems in obtaining this alphabetic sequence from computistical circles in Ireland or in north-eastern France in the early eighth century.

number of calendar and lunar days per month

In the Nivelles calendar, each month is headed by the number of Julian calendar days and lunar days (e.g., 31 and 30 respectively for March; cf. Facsimile 4). The length of each Julian calendar month could easily be deduced from Macrobius or the passages quoted above. ${ }^{98}$ The number of lunar days per month is more interesting, because this entailed considerable computistical knowledge, at least in application. First, to use this information sensibly, the reader needed to know that the number of lunar days listed before each Julian calendar month referred to the lunar month ending in that specific month, not beginning in it. E.g., in the $19^{\text {th }}$ year of the 19-year cycle, the lunar age on 1 January was 27; thus, the January lunation ended with luna 30 on 4 January, and the lunation that began with luna 1 on 5 January belonged to February. There were exceptions to this rule, which made the system moderately complex. ${ }^{99}$

From a retrospective viewpoint, the common way of distributing full and hollow lunar months was in alternating sequence, as found in all early medieval calendars: January 30, February 29, March 30 , April 29, etc. For a computist around AD 700, the situation was less clear-cut. The early Middle Ages knew three different Easter reckonings, the latercus, Victorius, and Dionysius. ${ }^{100}$ None of the original authors of these systems was specific about the sequence of lunations employed. From the data available, computists (unanimously, as far as the surviving evidence goes) reconstructed the alternating sequence for Victorius. The latercus used an interesting alternative, which assigned hollow lunations (of 29 days) to short Julian calendar months (of 30 days), full lunations (of 30 days) to long Julian calendar months (of 31 days). ${ }^{101}$ When faced with the Dionysiac Easter table, Irish computists had thus already experienced two different methods. The Dionysiac system appeared to represent a third option: the lunar data for years 8,11 , and 19 of the 19-year cycle suggested a full April lunation (of 30 days). Thus, some Irish computists reconstructed a sequence of January 30 , February 29, March and April 30, May and June 29, July 30, August 29, September 30, October 29, November 30, December 29. The Munich Computus is explicit about this sequence of lunations. ${ }^{102}$ The Computus Einsidlensis applies it, but then lists the alternating one for Dionysius; ${ }^{103}$ I suspect that a later copyist replaced the older interpretation by his own custom. Certainly, the Computus

\footnotetext{
${ }^{98}$ See above, section on 'Calendrical knowledge in seventh-century Ireland'.

${ }^{99}$ These exceptions are best explained by Helperic, Liber de computo ch. 36 (PL vol. 137, col. 46-47).

${ }^{100}$ The latercus is edited by D. Mc Carthy, 'Easter principles and a fifth-century lunar cycle used in the British Isles', Journal for the History of Astronomy 24 (1993), pp. 204-24, esp. 218-19; an English translation is provided by B. Blackburn and L. Holford-Strevens, The Oxford Companion to the Year: An Exploration of Calendar Customs and Time-reckoning (Oxford: Oxford University Press, 1999), pp. 870-75. Victorius' and Dionysius computistica are edited by Krusch, Studien, pp. 4-52, 59-86 respectively. A quick overview over these reckonings and their differences is provided by Warntjes, 'Computus as scientific thought', pp. 159-68. For their technical details, see especially Holford-Strevens, 'Paschal lunar calendars', pp. 178-205.

${ }^{101}$ See especially I. Warntjes, 'The Munich Computus and the 84 (14)-year Easter reckoning', Proceedings of the Royal Irish Academy 107C (2007), pp. 31-85, esp. 41-3 and the reference in the following note, which discuss all surviving evidence. B. Davis, 'The lunar year of the Coligny calendar as a precedent for the insular lunar year', Talanta 38-39 (2006-7), pp. 9-34, now argues that this sequence of lunations also formed the basis of the famous second-century Coligny calendar.

${ }^{102}$ Munich Computus ch. 50 (Warntjes, Munich Computus, p. 178, with further references).

${ }^{103}$ Einsiedeln SB 321 (647), pp. 109-11.
} 
Einsidlensis provides us with a flavour of the shift from the earliest Irish interpretation of the Dionysiac sequence of lunations to the alternating one that was to become the standard from the AD 720s onwards. The third Irish computistical textbook, De ratione conputandi, stands at the end of this development, vehemently arguing for the alternating sequence, while explicitly condemning the older alternative: ${ }^{104}$

Sciendum nobis quomodo menses lunares mensibus solis apud Grecos et Latinos secundum hanc regulam iunguntur. Ita etiam, id est .xxx. luna lanuario, .xxviiii. Feburario, .xxx. Martio, .xxviiii. Apreli (etsi alii dicunt lunam Aprelis .xxx.mam esse semper apud Grecos, quod non sinit natura, nisi in tribus annis tantum, id est quando .xxvi. uel .xxvii. uel .xxviiii. in Kalendis lanuarii fit. Nisi enim in his tribus annis .xxx.ma fuerit luna Aprelis, .xiiii. lunae primi mensis, quae contra Maium regulantur, non erunt in naturalibus mensis diebus); .xxx. Maio, .xxviiii. Iunio, .xxx. Iulio, .xxviiii. Agusto, .xxx. Septimbri, .xxviiii. Octimbri, .xxx. Nouimbri, .xxviiii. Decimbri.

'It should be known to us, how the Greek and the Latins link the lunar months to the solar months according to this rule: luna 30 in January, 29 in February, 30 in March, 29 in April (though some say that luna 30 always belongs to April according to the Greeks; this nature does not generally allow, but only in the three years with epact 26, 27, or 29 on 1 January; in fact, if there was not luna 30 in April in these three years, the full moons of the first month, which are towards against May, would not be on the natural days of the month), 30 in May, 29 in June, 30 in July, 29 in August, 30 in September, 29 in October, 30 in November, 20 in December.'

Table 4: The different sequences of lunations known in the seventh century.

\begin{tabular}{|c|c|c|c|c|}
\multicolumn{1}{c|}{ Month } & latercus & Victorius & Dionysius 1 & Dionysius 2 \\
\hline January & 30 & 30 & 30 & 30 \\
\hline February & 29 & 29 & 29 & 29 \\
\hline March & 29 & 30 & 30 & 30 \\
\hline April & 29 & 29 & 30 & 29 \\
\hline May & 30 & 30 & 29 & 30 \\
\hline June & 29 & 29 & 29 & 29 \\
\hline July & 30 & 30 & 30 & 30 \\
\hline August & 30 & 29 & 29 & 29 \\
\hline September & 29 & 30 & 30 & 30 \\
\hline October & 30 & 29 & 29 & 29 \\
\hline November & 29 & 30 & 30 & 30 \\
\hline December & 30 & 29 & 29 & 29 \\
\hline
\end{tabular}

${ }^{104}$ De ratione conputandi ch. 72 (Walsh and Ó Cróinín, Cummian's Letter, pp. 179-80); cf. Warntjes, Munich Computus, pp. XCIV, CXCVIII-CC. 
By the early eighth century, at the end of the debate outlined above and at the time when the genre of calendars took off, the alternating sequence seems to have been universally accepted for the Dionysiac reckoning. Any maker of a calendar could have implemented this basic information from any pre-Bedan computistical textbook.

solstices and equinoxes

The dates of the solstices and equinoxes were crucial for early medieval computists. The Alexandrian reckoning set out the rule that Easter was supposed to fall on the first Sunday after the first full moon after the spring equinox, which Dionysius Exiguus linked to the council of Nicaea when he popularized this method in the Latin West. ${ }^{105}$ Of the three known Easter reckonings of the early Middle Ages, only the Alexandrian / Dionysiac system followed this rule. The latercus and Victorius ensured that Easter Sunday would always occur after the spring equinox; the Easter full moon, however, could fall before it. These two systems are also interesting because they followed different dates for the spring equinox: the latercus set it on 25 March, while Victorius was following Alexandria in preferring 21 March.

This already illustrates that two different traditions for the dates of the solstices and equinoxes circulated in the seventh and eighth centuries. The first was principally transmitted through Isidore's Etymologiae and De natura rerum. ${ }^{106} \mathrm{Here}$, the equinoxes and solstices fell on the eighth day before the Calends of the respective month, i.e. VIII Kal. Apr. (25 March; spring equinox), VIII Kal. Jul. (24 June; summer solstice), VIII Kal. Oct. (24 September; autumn equinox), VIII Kal. Ian. (25 December; winter solstice). It came to be associated with the 'Latins' or 'Romans' in computistical literature. The alternative 'Greek' dates, on the other hand, were not readily outlined in any source available to mid-seventh-century intellectuals. Dionysius, in the prologue to his Easter table, explicitly mentioned 21 March as the spring equinox, and the letter of the Alexandrian patriarch Proterius translated by Dionysius from Greek into Latin did the same. ${ }^{107}$ From this datum, the $12^{\text {th }}$ day before the Calends of April for the spring equinox, the remaining three dates for the summer solstice, the autumn equinox, and the winter solstices were inferred as also occurring on the $12^{\text {th }}$ day before the Calends of the respective month, mirroring 'Latin' practice: XII Kal. Apr. (21 March; spring equinox), XII Kal. Jul. (20 June; summer solstice), XII Kal. Oct. (20 September; autumn equinox), XII Kal. Ian. (21 December; winter solstice). All three Irish computistical textbooks refer to, in one form or another, both traditions, ${ }^{108}$ and explain the difference between these. ${ }^{109}$

${ }^{105}$ Dionysius, Epistola ad Petronium (Krusch, 'Studien', p. 65). For the spread of the myth that the Council of Nicaea in AD 325 codified this rule, see C.W. Jones, 'A legend of St. Pachomius', Speculum 18 (1943), pp. 198210, repr. in W.M. Stevens (ed.), Bede, the schools and the computes (Aldershot: Variorum, 1994), article VII. ${ }^{106}$ Isidore, Etymologiae ch. V 34.2-3 (edited and translated into Spanish by V. Yarza Urquiola and F.J. Andrés Santos, Isidoro de Sevilla, Etimologías, Libro V: De legibus - De temporibus (Paris: Les belles lettres, 2013), pp. 112-15); idem, De natura rerum ch. VIII 1 (edited by J. Fontaine, Isidore de Séville: Traité de la nature [Bordeaux: Féret et fils, 1960], p. 205).

${ }^{107}$ Epistola Proterii ch. 8 (Krusch, Studien, p. 277); Dionysius, Epistola ad Petronium (Krusch, 'Studien', p. 65). See also the mysterious Disputatio Morini lines 22-23 (edited by E. Graff, 'The recension of two Sirmond texts: Disputatio Morini and De divisionibus temporum', in Warntjes and Ó Cróinín [eds], Computus and its cultural context, pp. 112-42, esp. 141).

${ }^{108}$ Munich Computus ch. 38 (Warntjes, Munich Computus, pp. 102-5); De ratione conputandi ch. 47-50 (Walsh and Ó Cróinín, Cummian's Letter, pp. 157-62); for the Computus Einsidlensis, see the following note. 
Because only parts of the Nivelles calendar survive (25 December-10 April, 28 May-13 July), it cannot be ascertained if all solstices or equinoxes were noted. The 'Greek' tradition is recorded in both places in which it was to be expected, 21 March and 20 June. The 'Latin' tradition is mentioned on 25 December and 25 March (cf. Facsimile 4), but not on 24 June (probably that entry was already considered overloaded with the birth of John the Baptist and the reception in Ephesus of John the Evangelist). Two aspects are noteworthy: First, the spring equinox on 21 March is ascribed to the Greeks (cf. Facsimile 4), as was common, while the terminology changed for the summer solstice on 20 June secundum Egyptios. This may well reflect a very early stage in the recording of the 'Greek' tradition, when only the spring equinox was known from the available sources, and the remaining equinox and solstices need to be inferred (and therefore received a different terminology). More interesting is the recording of an alternative 'Greek' date for the spring equinox, on 22 March (cf. Facsimile 4). The terminology changed slightly from the 21 March to the 22 March entry, from secundum Grecos to apud Grecos. Apud for secundum is relatively unusual in the calendar tradition (but not in computistical texts), but in the Nivelles calendar it recurs in the entries of the 'Latin' spring equinox on 25 March and summer solstice on 24 June, a tradition followed apud Latinos. This indicates that the unusual 22 March for the alternative 'Greek' spring equinox was taken from the same source as the 'Latin' entries. The Bobbio Computus transmits an interesting passage that shows the exact same characteristics (though not using apud): it discusses all 'Latin' equinoxes and solstices, but only one Greek alternative, the spring equinox on 22 March. ${ }^{110}$ The reason for assigning 22 March to the spring equinox rather than the computistical 21 March is theological, and best explained by the eighth-century Irish tract Dial. Langob.: ${ }^{111}$ If the celestial objects, including sun and moon, were created on the fourth day of creation, and if this coincided with the Latin spring equinox on 25 March, then 22 March was the first day of creation, which the Greeks considered as more appropriate for the spring equinox.

Thus, the Nivelles calendar's information for the equinoxes and solstices very well reflects the mindset of early eighth-century Irish computists. Bede, in one of his more dogmatic chapters, discusses the difference between 'Latin' and 'Greek' tradition, only to conclude that the 'Latin' dates violate the universal paschal doctrine of celebrating Easter after the equinox. ${ }^{112} \mathrm{~A}$ calendar taking Bede as its authority for the computistical entries could not record these misleading dates.

The moveable feasts dependent on Easter

The spring equinox leads directly into Easter calculations proper. For calendar makers, obviously the Julian calendar limits for Easter Sunday were the most significant information. Of the three Easter calculations of the early Middle Ages, each had a different range: latercus 26 March-23 April; Victorius 22 March-24 April; Dionysius 22 March-25 April. As mentioned earlier, all calendars that have survived are Dionysiac. ${ }^{113}$ Thus, invariably (and frequently) the Julian calendar limits of 22 March-25 April are recorded in this genre of texts, at is the case in the Nivelles calendar under 22

${ }^{109}$ Computus Einsidlensis (Einsiedeln SB 321 (647), pp. 98-99); Munich Computus ch. 38 (Warntjes, Munich Computus, pp. 106-07). De ratione conputandi does not have a similar passage, but cf. the Irish Dial. Langob. discussed below (n. 111). See also Nothaft, Scandalous Error, pp. 29-33.

${ }^{110}$ Bobbio Computus ch. 29, 45 (PL vol. 129, cols 1291, 1297; Milan BA H 150 inf., 14r, 19r-v). The first of these chapters can also be found in the Irish computus in Brussels KBR 8654-72, 203v-205v: 204r.

${ }^{111}$ Dial. Langob. ch. 18 (Borst, Schriften, pp. 448-50).

${ }^{112}$ Bede, De temporum ratione ch. 30 (Jones, Bedae opera, pp. 235-37).

${ }^{113} \mathrm{Cf}$. n. 51 above, and also the following note. 
March (cf. Facsimile 4). ${ }^{114}$ Easter Sunday regulates all other moveable feasts of the liturgical calendar, which principally are Lent, Rogation, and Pentecost. Historically, Lent entered the computistical discussion at a very early stage, as it already constituted a column in the latercus of the early fifth century. ${ }^{115}$ Rogation and Pentecost become part of this discussion in the second half of the eighth century and the early ninth century at the latest, respectively. ${ }^{116}$ Unsurprisingly, then, the Nivelles calendar does not include any reference to Pentecost. Whether Rogation was noted anywhere must remain speculative, as its dates fall into the calendar's first lacuna.

The initium quadragesimae, the beginning of the Lenten fast, however, features prominently in the Nivelles calendar, which records the Julian calendar limits of the sixth Sunday before Easter, 8 February ( VI Id. Feb.) to (and inclusive) 14 March (IIId. Mar.), under the first day of this range. It is important to remember that one of the main desiderata in Bede's accounts of time reckoning, his De temporibus of $A D 703$ and his lengthy De ratione temporum of AD 725, is a discussion of Lent. This demonstrates that some key computistical information could not be found in Bede's works by early medieval calendar makers. In Irish computistical textbooks of the early eighth century, on the other hand, Lent features prominently. The earliest two of these textbooks, the Computus Einsidlensis and

${ }^{114}$ Some calendars mark 24 April as the end of the Easter period, which could refer to Victorian practice. This, however, is simply a scribal error, a misplacement one line too early of the Dionysiac end of the Easter period on 25 April, as can be demonstrated by the only calendar of the 'major recensions' listed by Borst to have this feature (Reichskalender, pp. 809, 812), his calendar C6 = Melk SB 412, 44-55 (Auxerre, AD 836-854?): This calendar frequently lists computistical entries one or two days too early, which is best illustrated by the recording of the $7^{\text {th }}$ and $3^{\text {rd }}$ embolisms on 4 and 5 March, which are then, realizing the mistake, connected to the following entries by drawing a line to 5 and 6 March respectively, the correct places (p. 46); in April, the last possible date of the beginning of the Easter lunation ( 5 April) and the last possible date of the Easter full moon (18 April) are correctly recorded for the Dionysiac reckoning, which implies that the last possible date for Easter Sunday was also supposed to follow this reckoning (i.e. to be recorded on 25 April) and was simply misplaced (one line too early, 24 April). More interesting is the note in calendars F2-3, 7, G4, H1-4 of Borst's edition for 23 April that this date constitutes the 'end of the Easter of the Latins' (Borst, Reichskalender, pp. $806,808)$. The classification of 'the Latins' makes it immediately evident that the calendar makers here are referring to a tradition not their own, and at least F2 and G4 record the more appropriate custom of 'the Egyptians' on 25 April (Borst, Reichskalender, pp. 813-14, 816). Where this information originally came from, is an interesting question. The most obvious explanation is Victorius, Epistola ad Hilarum ch. 4 (Krusch, 'Studien', p. 19), where Victorius outlines the practice, before his reform, of the 'Latins' of Julian calendar limits for the Easter new moon of 5 March to 2 April (see also Borst, Reichskalender, pp. 651, 653, 751, 753, which Borst misunderstands), and Easter lunar limits of 16 to 22; this leads to the last possible Easter date being 23 April, luna 22. An interesting, though highly unlikely alternative possibility is that at least F2 (Karlsruhe BLB Aug. per. $167,16 \mathrm{v}$; the only calendar in Irish script; see $\mathrm{nn} .128,157-8$ ) here originally refered to the latercus rather than the Latini (the term is abbr. as lati-). It certainly should be stressed again that all of these calendars followed the Dionysiac / Alexandrian reckoning.

${ }^{115}$ See Mc Carthy, 'Easter principles', pp. 218-19 (edition); Blackburn and Holford-Strevens, The Oxford Companion to the Year, pp. 870-75, esp. 873-75 (translation); Warntjes, '84 (14)-year Easter reckoning', pp. 8082 (facsimile).

116 The rogation features in the Victorian Easter table of AD 720-4 discussed in n. 120; in the Dionysiac context, the rogation is fully established by the time of Lect. comp. ch. I 12-14 of AD 760 (Borst, Schriften, pp. 556-60); the most substantial discussion can be found in the unpublished Computus of AD 789 (Fulda UB F III 15k, 36r49r), which was the model for relevant chapters in Hrabanus Maurus' De computo; cf. Warntjes, 'Köln', pp. 5456, 83-88. For Pentecost, see Lib. calc. ch. 7 (Borst, Schriften, pp. 1391-92); the earliest calendar to record this may be Berlin SBPK Phillipps 1831, 2v (AD 800-810, Verona); note that many calendars record Primum Pentecosten on 15 May (Borst, Reichskalender, pp. 891-92), which is not to be confused (as Meyvaert, 'Discovering the calendar', pp. 28-29 does) with the first day of the 35-day Pentecostal range, which starts on 10 May (Borst, Reichskalender, pp. 875, 878); Primum Pentecosten on 15 May refers to the historic event of the Holy Spirit enlightening the apostles, corresponding to Christ's resurrection on 27 March; cf. also Borst, Kalenderreform, p. 426. 
the Munich Computus, explain in detail how to calculate the beginning of Lent. ${ }^{117}$ De ratione conputandi of c.AD 720s, explicitly refers to the Julian calendar limits, here 7 February to 14 March (probably an exclusive count or a copying error). ${ }^{118}$

In Frankish computistics, a similar development can be reconstructed. The Anglo-Saxon missionary Willibrord introduced the Dionysiac Easter calculation to the Frankish kingdoms when he moved from Ireland to the Frankish-Frisian border in AD 690. None of the three texts with computistical information he brought with him, his calendar, Easter table, and computistical formulary, contain any information about Lent. ${ }^{119}$ The recipient Frankish culture, at this time still firmly following Victorius, was more alert to the importance of Lent. A Victorian Easter table covering the years AD 700-770, and the Easter table in the Burgundian Dialogue of AD 727, contain a column for the beginning of Lent, probably following Irish examples. ${ }^{120}$ When Dionysius got more widely accepted in the Frankish kingdoms in the AD 730s, Lent features more prominently. The earliest Frankish Dionysiac textbook of AD 737 contains a list of the 19 termini quadragesimae (the equivalent to the Easter full moon; it is generally luna 2 of the lunar month preceding the Easter lunation, i.e. exactly 6 weeks before the Easter full moon, but here luna 3, the earliest possible lunar age of the beginning of Lent), and explains that the beginning of Lent is to be set on the Sunday following these fixed Julian calendar dates. ${ }^{121}$ The unpublished Computus Rhenanus of AD 776 contains rules of how to quickly calculate the beginning of Lent and its lunar age. ${ }^{122}$ By the time of the Computus of AD 789, the moveable feasts in the Dionysiac reckoning are established as an integrated part of Frankish computistics. Here, the Julian calendar limits of the beginning of Lent are explicitly mentioned. ${ }^{123}$

This demonstrates that the Julian calendar limits for the Dionysiac beginning of Lent could easily have been calculated from information available to Irish computists at around $A D 700$, to Frankish computists around the AD 730s. By the AD 720s texts circulated in Ireland from which the Julian calendar limits of the Dionysiac beginning of Lent could simply be copied, and the same applied to the Frankish kingdoms a few decades later.

Of the moveable data related to Easter calculation, the Nivelles calendar also records the Julian calendar limits for the Easter new moon (8 March to 5 April, noted under the first day of this range; cf. Facsimile 4). This information was readily available to computists and calendar makers through

${ }^{117}$ Einsiedeln SB 321 (647), pp. 119-122; Munich Computus ch. 58 (Warntjes, Munich Computus, pp. 230-41).

118 De ratione conputandi ch. 103 (Walsh and Ó Cróinín, Cummian's Letter, p. 207).

${ }^{119}$ For Willibrord's calendar, see n. 13; for his Easter table, n. 19; for his formulary of calendrical algorithms, n. 20.

120 The Victorian Easter table of AD 700-770 is transmitted in Vatican BAV Reg. lat. 586, 9v-10v (Lake Constance region?, saec. IX ${ }^{\text {inf }}$ ?); Paris BnF Lat. 4860, 147v-148r (Reichenau, saec. IX ${ }^{\mathrm{ex}}$ ); cf. Warntjes, Munich Computus, pp. LXXXIV-LXXXV. Dial. Burg. ch. 16 (Borst, Schriften, pp. 368-72); the Victorian Easter table for the years equivalent to AD 720-724 in Paris BnF Lat. 10756, 66v-67r not only records the beginning of Lent, but also the rogation; Paris BnF Lat. 10756 and Bern BB 611, which transmits the only surviving copy of Dial. Burg., originally formed one manuscript from the first half of the eighth century; cf. https://www.ecodices.unifr.ch/de/description/bbb/0611/Mittenhuber, accessed 14 August 2020; the Paris codex is available online at: https://gallica.bnf.fr/ark:/12148/btv1b9065920c.r=10756?rk=42918;4, accessed 14 August 2020; the Victorian Easter table therein is transcribed and discussed in Krusch, 'Chronologisches', pp. 93-94.

${ }^{121}$ Dial. Neustr. ch. 19 (Borst, Schriften, pp. 400-01).

122 Cologne DB 103, 186r-v (AD 798, Cologne; available online at: www.ceec.uni-koeln.de, accessed 14 August 2020); Wolfenbüttel HAB Cod. Guelf. 91 Weiss., 170r-v (Worms or Weissenburg, saec. IX ${ }^{1 / 2}$; available online at: http://diglib.hab.de/?db=mss\&list=ms\&id=91-weiss, accessed 14 August 2020). For this text, see Warntjes, 'Argumenta', pp. 43, 70, 75-77, 101-2; idem, 'Computus Cottonianus', pp. 189-90, 199-203, 207-12; 'Köln', 6264.

${ }^{123}$ Cf. n. 116. See also Lect. comp. ch. VI 1 (Borst, Schriften, pp. 613-14); this section of the text is datable to AD 790 (cf. Warntjes, 'Köln', pp. 61, 66-67). 
Victorius of Aquitaine's Letter to Archdeacon (later Pope) Hilarus of AD 457, or Dionysius' Letter to Petronius, or Isidore of Seville's Etymologiae. ${ }^{124}$ It can also be found in all three Irish computistical textbooks of the early eighth century. ${ }^{125}$ What is interesting here is the choice made by the calendar maker: Focusing on the Easter new and full moons, Easter Sunday, and Lent, but not on Rogation or Pentecost speaks for its early composition in the first half of the eighth century rather than the second.

bissextus

In the Nivelles calendar, the additional day in leap-years (bissextus) is noted under 24 February. This information could readily be obtained from the Macrobian excerpt called Disputatio Chori et Praetextati discussed above, which circulated widely in the early Middle Ages. ${ }^{126}$ Thus, the calendar maker here only states common knowledge, and it appears that no further comment is needed. Still, it is worth keeping in mind that this date became standard only in the eighth century. The earliest two Irish computistical textbooks, the Computus Einsidlensis and the Munich Computus, still experimented with two other options: 2 March as suggested by a rather obscure passage in Isidore's Etymologiae, and 21 March, understood as the first day of creation. ${ }^{127}$ Interestingly, remnants of this seventh-century debate can still be found in some calendars with strong Irish connections. ${ }^{128}$ The

${ }^{124}$ Victorius of Aquitaine, Epistola ad Hilarum ch. 4 (Krusch, 'Studien', p. 20): Sancte memoriae contra Theophilos quondam Alexandrinus antestis ad Theodosium imperatorem datis epistolis, ex primo ipsius et Gratiani quinto consulate conditum paschale direxit, in quo ab VIII. idus martias usque in diem nonarum aprilium, quolibet in medio eiusdem temporis spatio natam perhibit lunam, facere primi mensis exordium. Dionysius, Epistola ad Petronium (Krusch, 'Studien', p. 65): Sed quia mensis hic, unde sumat exordium vel ubi terminetur, evidenter ibi non legitur, praefati venerabiles CCCXVIII pontifices antique moris observantiam et exinde a sancto Moyse traditam, sicut in septimo libro ecclesiasticae refertur historiae, sollertius investigantes, ab VIII. Idus Martii usque in diem Nonarum Aprilis natam lunam facere dixerunt primi mensis exordium. Isidore of Seville, Etymologiae ch. VI 17.20 (edited and translated into Spanish by C. Chaparro Gómez, Isidoro de Sevilla, Etimologías, Libro VI: De las Sagradas Escrituras [Paris: Les belles lettres, 2012], pp. 104-5): Greci primi mensis lunam ab octauo Idus Martias usuqe in die Nonas Apriles obseruant.

125 Einsiedeln SB 321 (647), p. 111; Munich Computus ch. 55 (Warntjes, Munich Computus, pp. 216-17); De ratione conputandi ch. 90 (Walsh and Ó Cróinín, Cummian's Letter, p. 197).

${ }^{126}$ Disputatio Chori et Praetextati ch. 18 (Holford-Strevens, Roman Calendar for Beginners, pp. 80-81).

${ }^{127}$ See especially Einsiedeln SB 321 (647), pp. 105-06; Munich Computus ch. 41 (Warntjes, Munich Computus, pp. 130-31). Cf. Warntjes, Munich Computus, pp. CXLIII-CXLIV, CXXXIX; M. Smyth, 'Once in four: the leap year in early medieval thought', in I. Warntjes and D. Ó Cróinín (eds), Late Antique Calendrical Thought and Its Reception in the Early Middle Ages (Turnhout: Brepols, 2017), pp. 229-64, esp. 230-36; Nothaft, Scandalous Error, pp. 25-26.

${ }^{128}$ Of the calendars collated by Borst, 2 March according to Isidore as a potential place for the bissextile day is only recorded in the only calendar in Irish script, Karlsruhe BLB Aug. perg. 167, 16v (Soisson-Laon, c.AD 848; online at: https://digital.blb-karlsruhe.de/blbhs/content/titleinfo/20736, accessed 14 August 2020), and its copy St Gall SB 248, p. 73 (Soisson-Laon c.AD 850; online at: https://www.ecodices.unifr.ch/de/list/one/csg/0248, accessed 14 August 2020); cf. M. Schneiders, 'The Irish calendar in the Karlsruhe Bede (Karlsruhe, Badische Landesbibliothek, Cod. Aug. CLXVII, ff. 16 $\left.6^{\vee}-17^{\vee}\right)^{\prime}$ ', Archiv für Liturgiewissenschaft 31 (1989), pp. 33-78, esp. 46, 66. See also the two later Spanish calendars in El Escorial RB d.I.2, 6r-v (Albelda, 974-6) and Silos AM 4 (Albelda, 1052). The bissextus on 21 March is not listed in any calendar used by Borst, but interestingly another Irish feature can be found on this date, the saltus, which is only recorded in Vatican BAV Ottob. Lat. 67, 23r (Angers?, c.AD 978?, based on a northern Italian exemplar of c.AD 810) and Karlsruhe BLB Karlsruhe 442, 40v (Angers?, saec. X/XI?; available online at: https://digital.blbkarlsruhe.de/blbhs/Handschriften/content/titleinfo/2589900, accessed 14 August 2020). Meyvaert, 
Nivelles calendar is beyond that stage, and, as in the data for the initium quadragesimae, resembles the last of these three Irish textbooks (De ratione conputandi) more than the first two. ${ }^{129}$

epact

Like the bissextus on 24 February, it was common knowledge that the epactae that constituted the second column in Dionysius' Easter table refer to the lunar age on 22 March. The first Latin author to explicitly mention this date, interestingly, was not Dionysius himself, but Isidore. ${ }^{130}$ Through his Etymologiae, one of the most popular texts of the early Middle Ages, this datum circulated widely. The Irish computistical textbooks also note it, ${ }^{131}$ though they preferred to calculate from the lunar age of 1 January as they had been accustomed to from the latercus and Victorius. ${ }^{132}$ If noting the epact on 22 March thus is fairly non-indicative, it is worth pointing to an omission by the Nivelles calendar maker: A year is generally characterized by two data in combination, the lunar age and the weekday of a given day. In the latercus and the Victorian reckoning, 1 January was chosen for both. In Dionysius' Easter table, the lunar age on 22 March was matched by the weekday on 24 March, called the concurrent. That very term is nowhere to be found in the Irish computistical textbooks, ${ }^{133}$ and it may be significant that the Nivelles calendar does not provide this information under 24 March.

second month

The Nivelles calendar provides unusual information for 1 April: initium secundi mensis. Generally, in the early medieval calendar tradition, April was considered the first, not the second month, based on Bede. ${ }^{134}$ The entry in the Nivelles calendar reflects pre-Bedan practice, mirroring a passage preserved in the Munich Computus: ${ }^{135}$ Primus mensis apud Hebreos Martius, quia in eo mundus factus est, et primum phase factum est, conception et passio et resurrectio Christi. The author is explicit why March is considered the first month: the world was created in this month (21 March), the first passover happened in it, as did the conception ( $25 \mathrm{March}$ ), passion and resurrection of

'Discovering the calendar', pp. 33-34 ascribes the recording of this datum explicitly to Bede, because he believes that the Vatican calendar is the closest to Bede's original now lost; it is rather an Irish feature (cf. Warntjes, Munich Computus, XLVIII-XLIX n. 111, 278-81, 284 f.). The computistical contents of Karlsruhe 442 with a copy of De computo dialogus and a recension of De divisionibus temporum reveals and ultimately Irish background. Cf. also the calendar in Florence BML Plut.16.8, 2r (Florence, saec. XI ${ }^{\text {mid }}$; available online at: http://mss.bmlonline.it/s.aspx?ld=AWOHy4AYIA4r7GxMB2H\&c=Martyrologium\%20Bedae\#/oro/13, accessed 14 August 2020). See Borst, Reichskalender, pp. 643, 645, 697, 700-1.

${ }^{129}$ See especially De ratione conputandi ch. 57 (Walsh and Ó Cróinín, Cummian's Letter, pp. 168-69). Cf. Warntjes, Munich Computus, p. CXCVIII.

${ }^{130}$ Isidore of Seville, Etymologiae ch. VI 17.31 (Chaparro Gómez, Isidoro de Sevilla, pp. 108-09).

${ }^{131}$ See especially Einsiedeln SB 321 (647), p. 109; Munich Computus 49 (Warntjes, Munich Computus, pp. 16869); De ratione conputandi ch. 103 (Walsh and Ó Cróinín, Cummian's Letter, p. 207).

${ }^{132}$ Cf. Warntjes, Munich Computus, pp. LXXII-LXXIII, CLXII-CLXIII.

${ }^{133}$ Cf. ibid., p. LXXIII n. 188.

134 Borst, Reichskalender, pp. 743-44, 746.

135 Munich Computus ch. 24 (Warntjes, Munich Computus, p. 64). 
Christ (25 and 27 March respectively). The ascription of this tradition to the Hebrews stems from Isidore. ${ }^{136}$ It is important to note that the Munich Computist's statement here can be explained independent of the calendar tradition, which provided similar information. Polemius Silvius equated March with Nisan, the first month of the Hebrew lunar year. ${ }^{137}$ Early in the eighth century at the latest, the correlation between Roman and Hebrew months was shifted by one, leading to the equation of Nisan with April. April thus became the first month. ${ }^{138}$ The Munich Computist is still confused about the issue, clinging to the old tradition of March being the first month, but appearing irritated by the fact that this is supposed to be Hebrew Adar (the month before Nisan). ${ }^{139}$ By the time of De ratione conputandi and Bede's De temporum ratione, i.e. by the AD 720s, the new theory of Nisan equaling April as the first month was fully developed, and through Bede it became popular in subsequent calendars. ${ }^{140}$ Recording the older tradition of March being the first month (and April thus the second) is a clear indication of a pre-Bedan layer.

creation of the world

Another, but more obvious and more indicative feature of pre-Bedan Irish computistical theory, is the information provided on the creation of the world. For 21 March, the Zürich / Nivelles calendar notes equinoctium secundum Grecos et primius [recte primus] dies seculi. Connecting the spring equinox with the first day of creation was a common feature in pre-Bedan computistical theory. The fifth-century text called the Acts of the Council of Cesarea argues that the world was created on a Sunday, 25 March, the spring equinox. ${ }^{141}$ Victorius of Aquitaine, in his Prologue of AD 457, also mentions this older Roman tradition (carefully avoiding to refer to it as the spring equinox). ${ }^{142}$ With the adoption of the Alexandrian / Dionysiac Easter reckoning with its 'Greek' spring equinox of 21 March, it was only natural to shift this theory to this earlier date, i.e. first day of creation on 21 March. Sixth- and seventh-century computists tried to justify this shift by arguing that the old Roman equinox of 25 March should be considered the fourth day of creation, when the heavenly bodies came into existence. Thus, the first day of creation was supposed to have happened three days earlier, on 22 March. This is how the late-fifth, early sixth-century text variously ascribed to Athanasius, Sulpicius Severus, and Martin of Braga portrays it. ${ }^{143}$ This pushed the first day of creation to $22 \mathrm{March}$, but not $21 \mathrm{March}$. The final piece in the puzzle was the argument that the days of creation should be considered lunar days, starting at midday of the preceding Julian calendar day

\footnotetext{
${ }^{136}$ Isidore, De natura rerum ch. 6.2 (Fontaine, Traité de la nature, p. 193).

137 Polemius Silvius, Fasti (Mommsen, Corpus inscriptionum latinarum 1, p. 339).

${ }^{138}$ See especially C.W. Jones, 'Polemius Silvius, Bede, and the names of the months', Speculum 9 (1934), pp. 50-56.

${ }^{139}$ Munich Computus ch. 55 (Warntjes, Munich Computus, pp. 210-13).

${ }^{140}$ De ratione conputandi ch. 41 (Walsh and Ó Cróinín, Cummian's Letter, p. 150); Bede, De temporum ratione ch. 11 (Jones, Bedae opera, p. 203).

${ }^{141}$ The Acta Synodi Cesareae exists in four recensions, labeled A to D; the B-recension, published in PL vol. 90, cols 607-10, was the most widely used in the early Middle Ages. A new study of the complex history of this text by Leofranc Holford-Strevens is in preparation.

142 Victorius of Aquitaine, Epistola ad Hilarum ch. 7 (Krusch, 'Studien', p. 23): octavo kalendarum aprilium, quo mundus traditur institutus.

${ }^{143}$ This work is certainly not from Martin of Braga's pen. It circulated in different recensions; a full-scale study with edition and translation by Alden Mosshammer and myself is in preparation. For the passage in question see C.W. Barlow, Martini episcopi Bracarensis Opera omnia (New Haven: Yale University Press, 1950), pp. 27273; Krusch, Studien, pp. 331-32; A. Strobel, Texte zur Geschichte des frühchristlichen Osterkalenders (Münster: Aschendorffsche Velragsbuchhandlung, 1984), pp. 109, 113-14.
} 
according to early medieval Irish computists. ${ }^{144}$ Therefore, the first day of creation began in the evening of 21 March. The Munich Computus explains this theory in detail, ${ }^{145}$ lists both traditions (Greek and Roman) for the first day of creation (21 and 25 March respectively), ${ }^{146}$ but insists on the Greek tradition as the binding one. ${ }^{147}$ Shortly after the composition of the Munich Computus of AD $718 / 9$, De ratione conputandi mentions only the Greek date, ${ }^{148}$ and such Irish texts inform the Zürich / Nivelles calendar.

Bede, in $A D 725$, revisited the theory, and felt the need for further improvement. ${ }^{149}$ The equinox is the date of equal periods of day and night (12 hours each). God made all things equal. Therefore, the heavenly bodies on the fourth day surely must have been created at the equinox. The correct spring equinox is that of the Greeks, 21 March. The first day of creation, accordingly, happened three days earlier, on 18 March (which coincides with the entry of the sun in the zodiac sign of Aries). Thus, Bede pushed the first day of creation forward by another 3 days to $18 \mathrm{March}$, and this is the information found in almost every early medieval calendar that records this datum. ${ }^{150}$ The alternative of 21 March is very rare ${ }^{151}$ but highly indicative characteristic of a pre-Bedan layer most prominently expressed in early eighth-century Irish texts.

increase and decrease of daylight

Possibly the most indicative feature of Irish, pre-Bedan computistical influence in the Zürich / Nivelles calendar are the statements on the increase of daylight between 25 December and 25 March, the Roman winter solstice and spring equinox. The author of this calendar started on the assumption (not recorded) that there were 6 hours of daylight on the winter solstice (25 December). He then noted an increase of daylight of one hour per 15 days: on 9 January (VII hore in diae), 24 January (VII<I> hore in die), 8 February (VIIII hore in diae), 10 March (XI hore in diae), and 25 March (XII hore in die), missing only the 10 hours on 23 February. This theory is based on Anatolius Latinus' De ratione paschali. Anatolius Latinus outlined the theory that daylight increased by $22 / 3$ moments per day between the winter and the summer solstice, which he considered on the Roman dates ( 25 December, 24 June), like the author of the Zürich / Nivelles calendar; 40 moments complete an hour, and thus a daily increase of $22 / 3$ moments leads to a full hour in 15 days $(22 / 3 \times 15=40)$, as recorded by the Zürich / Nivelles calendar. This theory of a daily increase in daylight between the winter and the summer solstice is taken up and discussed in much more detail in the Irish computistical textbooks. The Computus Einsidlensis and the Munich Computus of the early eighth century transferred it to the Greek dates (21 December, 21 March, 20 June, 23 September). ${ }^{152}$ De

\footnotetext{
${ }^{144}$ For this beginning of the lunar day, ascribed to the Hebrews in Irish sources, see Munich Computus ch. 8 (Warntjes, Munich Computus, pp. 26-27), with a discussion of the most relevant contemporary sources.

145 Munich Computus ch. 44 (Warntjes, Munich Computus, pp. 146-49).

${ }^{146}$ Munich Computus ch. 11 (Warntjes, Munich Computus, pp. 42-43).

${ }^{147}$ Munich Computus ch. 36 (Warntjes, Munich Computus, pp. 98-99).

${ }^{148}$ De ratione conputandi ch. 68 (Walsh and Ó Cróinín, Cummian's Letter, p. 177).

149 Bede, De temporum ratione ch. 6 (Jones, Bedae opera, p. 192).

150 Borst, Reichskalender, pp. 687, 689-90.

${ }^{151}$ None of the calendars used by Borst contains a reference to the first day of creation on 21 (or 22) March; cf. Borst, Reichskalender, pp. 699-706.

152 Einsiedeln SB 321 (647), p. 99; Munich Computus ch. 39 (Warntjes, Munich Computus, pp. 110-17).
} 
ratione conputandi of a few years later proved more conservative, following the ultimate source (Anatolius Latinus) in its Roman dates. ${ }^{153}$ This is also the practice of the mid-eighth century Irish text Dial. Langob. ${ }^{154}$

It is interesting that the Zürich / Nivelles calendar records the one-hour increase (and decrease in the second half of the year) of daylight only in the first quarter of the year, between 25 December and 25 March. In the following months, the relevant entries remain empty. This may be a reaction to the earlier Irish debate, in which the first quarter of the year, between the winter solstice and the spring equinox, received special attention. According to these Irish texts, additional to the increase of daylight of $22 / 3$ moments per day the bissextile day grew by $11 / 3$ moment per day in this 90 -day period, amounting to the 3 hours that constitute a quarter of a 12-hour day. But whether these three extra hours were to be accounted for as daylight or nighttime or dusk and dawn, the authors found difficult to explain. The solution was a rather vague theory of a cloud (nubs) symbolized by dusk and dawn. The message of the Zürich / Nivelles author was that only the regular increase of daylight of $22 / 3$ moments per day was of relevance, the bissextile day should be accounted for by a different mechanism.

This theory of an increase of daylight between the winter and the summer solstice of $22 / 3$ moments remained extraordinarily popular throughout the Carolingian period. Only a full assessment of all computistical manuscripts before c.AD 900 will provide a solid insight into which monastic centers followed this concept popularized by Irish computists. It remains noteworthy that Bede showed no interest in this theory. In the early medieval calendar tradition, noting the length of day and night never became a standard feature, ultimately because of Bede's disinterest. If this feature is included in a calendar, then usually only at the solstices and equinoxes ${ }^{155}$ or, more frequently, at the end or beginning of each month, ${ }^{156}$ not in 15-day intervals as in the Zürich / Nivelles calendar. A noteworthy exception is the only surviving calendar in Irish script, now Karlsruhe BLB Aug. perg. 167, and its copy now in St Gall. ${ }^{157}$ Pre-Bedan Irish influence kept its appeal in monastic centres that resisted the Carolingian standardization process on Bede's model.

\section{Conclusion: towards a generic model}

Arno Borst classified the entries in early medieval calendars in three categories:

\footnotetext{
${ }^{153}$ De ratione conputandi ch. 50 (Walsh and Ó Cróinín, Cummian's Letter, pp. 159-62).

${ }^{154}$ Dial. Langob. ch. 19C (Borst, Schriften, pp. 451-52).

${ }^{155}$ Cf. Borst, Reichskalender: spring equinox 21 March: pp. 697-98, 701; 24 March: pp. 710, 712; 25 March: pp. 713-14, 718; summer solstice: 19-20 June: pp. 998, 1000-01, 1003; 23-24 June: pp. 1011-13, 1016; autumn equinox: 20 September: pp. 1309, 1311; 23 September: pp. 1317, 1319; winter solstice: 20-21 December: pp. 1601, 1603-04, 1606; 24 December: pp. 1613-14.

${ }^{156}$ Borst, Reichskalender, pp. 420, 422, 525, 531-33, 623, 632-33, 733, 741-42, 832, 839-40, 935, 942-43, 1035, 1041-42, 1144, 1149-50, 1244, 1250-51, 1341, 1348, 1350, 1445, 1449-50, 1538, 1546-47, 1633.

157 Karlsruhe BLB Aug. perg. 167, 16v-17v (Soisson-Laon, c.AD 848; online at: https://digital.blbkarlsruhe.de/blbhs/content/titleinfo/20736, accessed 14 August 2020); St Gall SB 248, pp. $72-76$ (Soisson-Laon c.AD 850; online at: https://www.e-codices.unifr.ch/de/list/one/csg/0248, accessed 14 August 2020). Cf. especially Schneiders, 'Irish calendar', with an edition of the Karlsruhe calendar; for the St Gall codex, see especially A. Cordoliani, 'Les manuscrits de comput ecclesiastique de l'Abbaye de Saint Gall du VIII' au XII siècle', Zeitschrift für Schweizerische Kirchengeschichte = Revue d'histoire Ecclésiastique Suisse 49 (1955), pp. 161-200, esp. 168-77; for the relationship between the Karlsruhe and the St Gall calendar, see Borst, Reichskalender, pp. 228-31.
} 

a) liturgical / martyrological
b) computistical
c) astronomical

Of these, astronomical entries were an extension of computistical ones, and not essential for this genre of texts. In fact, they were introduced into calendars only with the reception of Pliny excerpts in the eighth century, and did not fulfill any role in Christian worship.

More important were the first two categories. A calendar was, essentially, a grid of 365 days, which were populated with entries important for the communities that produced them. The basic function was a liturgical reminder of key events, which comprised, principally, the feast days of saints considered most important for the communities in question (martyrological), and the basics of the moveable feasts of the liturgical calendar centred around Easter (computistical). It happened that either only martyrological, or only computistical data were noted. If it was only martyrological, it belonged to a different genre of texts, the martyrologies. If it was only computistical, it still classified as a calendar. Thus, the computistical entries are the defining criterion for an early medieval calendar.

If early medieval calendars with only computistical entries exist, they are extremely rare. ${ }^{158}$ Typically, they contain at least both martyrological and computistical data. Both are equally important for modern scholars. As extensive research of martyrologies has shown, martyrological entries can often be classified in various chronological layers that reveal the transmission history of the text. ${ }^{159}$ Surprisingly, computistical entries have not received similar attention. This may be due to the fact that there is a general, misguided perception that the computistical data recorded is, more or less exclusively, Bedan. ${ }^{160}$ This perception was instrumental in the reconstruction of the origin of early medieval calendars: a Roman model similar to Polemius Silvius' calendar was brought to Northumbria in the second half of the seventh century. There, it led to the construction of native calendars with a more strongly Christian purview. From Anglo-Saxon England, this new calendar type (whether at that stage already the prototype of the genre or not) travelled in the bag of scholars, missionaries, or pilgrims into the Frankish heartland in the second third of the eighth century. In the Carolingian Renaissance, production of calendars then increased on a massive scale, with a wide distribution throughout Western Europe.

The computistical data provides the key to a more generic model. Computistical theory was not uniform, it certainly was not only Bedan. Before Bede, computus developed into a major subject of monastic education in seventh-century Ireland, and regional characteristic were also developed in Visigothic Spain and Francia. Traces of these, especially of Irish thought, can be found in the earliest calendars that survive from the eighth century. This article has proven that all the computistical information found in one test-case calendar (Zürich UB Rh. 30, 166v-169v) provides an almost exact match with Irish computistical knowledge of the early eighth century (and not, it will be noted, Bedan thought). No Roman model was needed for the construction of an early medieval calendar

\footnotetext{
${ }^{158}$ Meyvaert, 'Discovering the calendar', pp. 12-16 hypothesized that Bede's calendar lacked martyrological entries, but besides computistical material also incorporated astronomical data. A good example mentioned by him is St Gall SB 248, pp. 72-76; note, however, that this is a copy of Karlsruhe BLB Aug. perg. 167, 16v-17v, which does contain martyrological entries. In other words, omitting martyrological entries here is the deliberate choice of a later copyist, not a marker of an early calendar close to Bede's time of writing (thus Borst, Reichskalender, pp. 228-31; contra Meyvaert, 'Discovering the calendar', pp. 40-42). Cf. previous note. ${ }^{159}$ See, e.g., the excellent studies by Pádraig Ó Riain assembled in his Feastdays of the saints.

${ }^{160}$ Meyvaert, 'Discovering the calendar', pp. 25-34 is only the most obvious example. Even Schneiders, 'Irish calendar', pp. 66-68 works from the premise that the computistical entries in the Carlsruhe calendar, the only one in Irish script, must have a Bedan origin.
} 
when this genre came to life towards the end of the seventh century. The 365-day grid could be reconstructed from the Macrobian excerpt known as Disputatio Chori et Praetexti or comparable and more compressed texts, and this grid was then populated not only by saints' feastdays of particular local relevance, but also by computistical characteristics developed in the same region. The origin of the early medieval calendar, therefore, is not only to be sought in the popular notion of Roman texts informing Anglo-Saxon scholars whose teaching laid the foundation for the Carolingian Renaissance. Calendars, no doubt, started to flourish independently in various places, without the need for a fixed model or centralized authority. The early medieval intellectual endeavour was more regional than modern master narratives would want to make us believe, and the calendar was no exception. In this context, it is worth reminding ourselves of Wallace-Hadrill's assessment of 1956:161

'I must leave the matter there. All I have done has been to hazard the suggestion that the devotion of the early English Church to Rome and to the name of Gregory the Great can a little blind us, even now, to the true nature of Rome's obligations towards England, some of which could only be fulfilled with the help of churches lying nearer to England than Rome herself lay. In England, at least, we need to be better informed about the state of the Frankish and the Visigothic churches, their teaching and learning and their ability to supply England with some of the books she needed. We need to learn not to be blinded by the highlights of insular calligraphy to the study of debased texts in humbler scripts and in barbarized Latin; and the completion of Lowe's Codices Latini will, some day, make a systematic appraisal of western manuscript resources in the sixth and seventh centuries a possibility at last. England is part of the picture. We have too long regarded her, as perhaps she liked to regard herself, as Rome's only peculiar child. In truth, do her difficulties, and the help she obtained from Rome in their solution, notably distinguish her from her sister-churches in the west? Everywhere we meet the same problems: of simony, of lay-seizure of church lands, of the foundation of false monasteries, of royal incursion on ecclesiastical privileges; and many more. These are the common problems of barbarian Christendom, as St. Boniface must only too well have known. What now needs investigation is not England's debt to Rome but Rome's activity in England as an integral part of her activity in Western Europe as a whole.'

One of the common intellectual problems of Western Christianity after the Fall of Rome was to construct a calendar grid that would guide the faithful through the liturgical year. At around AD 700, this problem could be solved anywhere in Western Europe without the need for a Roman model, or the stimulus of central authority. The key to our understanding of the early medieval calendar tradition lies in acknowledging a high standard of calendrical learning throughout the Latin West before Bede and the Carolingians, with flourishing regional diversity fostering different intellectual traditions.

\footnotetext{
161 J.M. Wallace-Hadrill, 'Rome and the early English church: some questions of transmission', in La chiese nei regni dell'Europa occidentale e i loro rapport con Roma sino all'800 (Spoleto: Centro italiano di studi sull'alto medioevo, 1960), pp. 519-48 (article), 575-82 (discussion), esp. 547-48.
} 


\section{Abbreviations}

CLA - Codices Latini Antiquiores

MGH - Monumenta Germaniae Historica

Auct. Ant. - Auctores antiquissimi

Conc. - Concilia

SS rer. Merov. - Scriptores rerum Merovingicarum

PL - Patrologia Latina

\section{$\underline{\text { References }}$}

R. Abels, 'The council of Whitby: a study in early Anglo-Saxon politics', Journal of British Studies 23 (1983), pp. 1-25.

A. Arweiler, 'Zu Text und Überlieferung einer gekürzten Fassung von Macrobius Saturnalia I,12,2I,15,20', Zeitschrift für Papyrologie und Epigraphik 131 (2000), pp. 45-57.

C.W. Barlow, Martini episcopi Bracarensis Opera omnia (New Haven: Yale University Press, 1950).

R. Bauerreiß, 'Ein angelsächsisches Kalendarfragment des bayrischen Hauptstaatsarchivs in München', Studien und Mitteilungen zur Geschichte des Benediktiner-Ordens und seiner Zweige 51 (1933), pp. 177-82.

J. Bisagni, 'The newly-discovered Irish and Breton computistica in Città del Vaticano, BAV, MS Reg. Lat. 123', Peritia 28 (2017), pp. 13-34.

J. Bisagni and I. Warntjes, 'Latin and Old Irish in the Munich Computus: a reassessment and further evidence', Ériu 57 (2007), pp. 1-33.

J. Bisagni and I. Warntjes, 'The Early Old Irish material in the newly discovered Computus Einsidlensis (c.AD 700)', Ériu 58 (2008), pp. 77-105.

B. Bischoff, Die südostdeutschen Schreibschulen und Bibliotheken in der Karolingerzeit, Teil 1: Die bayerischen Diözesen (3rd ed., Wiesbaden: Harrassowitz, 1974).

B. Bischoff, Die südostdeutschen Schreibschulen und Bibliotheken in der Karolingerzeit, Teil 2: Die vorwiegend österreichischen Diözesen (Wiesbaden: Harrassowitz, 1980).

B. Blackburn and L. Holford-Strevens, The Oxford Companion to the Year: An Exploration of Calendar Customs and Time-reckoning (Oxford: Oxford University Press, 1999).

A. Borst, Das Buch der Naturgeschichte: Plinius und seine Leser im Zeitalter des Pergaments (Heidelberg: Universitätsverlag C. Winter, 1994). 
A. Borst, Die karolingische Kalenderreform (Hannover: Hahn, 1998).

A. Borst, Der karolingische Reichskalender und seine Überlieferung bis ins 12. Jahrhundert, 3 vols (Hannover: Hahn, 2001).

A. Borst, Der Streit um den karolingischen Kalender (Hannover: Hahn, 2004).

A. Borst, Schriften zur Komputistik im Frankenreich von 721 bis 818, 3 vols (Hannover: Hahn, 2006).

V. Brown, 'Where have all the grammars gone? The survival of grammatical texts in Beneventan script', in P. de Paolis, M. de Nonno, and L. Holtz (eds), Manuscripts and Tradition of Grammatical Texts from Antiquity to the Renaissance, 2 vols (Cassino: Edizione dell'Università degli Studi di Cassino, 2000), pp. 389-414.

R.W. Burgess, 'The Chronograph of 354: its manuscripts, contents, and history', Journal of Late Antiquity 5 (2012), pp. 345-96.

R.W. Burgess, 'The new edition of the Chronograph of 354: a detailed critique', Zeitschrift für antikes Christentum 21 (2017), pp. 383-415.

C. Burnett, 'Translation and transmission of Greek and Islamic science to Latin Christendom', in D.C. Lindberg and M.H. Shank (eds), The Cambridge History of Science, vol. 2: Medieval Science (Cambridge: Cambridge University Press, 2015), pp. 341-64.

C. Burnett, 'The twelfth-century renaissance', in D.C. Lindberg and M.H. Shank (eds), The Cambridge History of Science, vol. 2: Medieval Science (Cambridge: Cambridge University Press, 2015), pp. 36584.

M.J. Carton, Three Unstudied Manuscripts of Macrobius' Saturnalia (unpublished Ph.D. thesis, St. Louis, 1966).

C. Chaparro Gómez, Isidoro de Sevilla, Etimologías, Libro VI: De las Sagradas Escrituras (Paris: Les belles lettres, 2012).

T.M. Charles-Edwards, Early Christian Ireland (Cambridge: Cambridge University Press, 2000).

B. Colgrave, The Life of Bishop Wilfrid by Eddius Stephanus (Cambridge: Cambridge University Press, 1927, repr. 1985).

B. Colgrave, The Earliest Life of Gregory the Great (repr. Cambridge: Cambridge University Press, 1985).

J.J. Contreni, 'The Carolingian Renaissance: education and literary culture', in R. McKitterick (ed.), The New Cambridge Medieval History, vol. 2: c.700-c.900 (Cambridge: Cambridge University Press, 1995), pp. 709-57, 1013-24.

J.J. Contreni,'Learning for God: education in the Carolingian Age', Journal of Medieval Latin 24 (2014), pp. 89-130. 
A. Cordoliani, 'Les manuscrits de comput ecclesiastique de l'Abbaye de Saint Gall du VIII' au XII' siècle', Zeitschrift für Schweizerische Kirchengeschichte = Revue d'histoire Ecclésiastique Suisse 49 (1955), pp. 161-200.

C. Corning, The Celtic and Roman Traditions: Conflict and Consensus in the Early Medieval Church (New York: Palgrave Macmillan, 2006).

E.T. Dailey, 'To choose one Easter from three: Oswiu's decision and the Northumbrian Synod of AD 664', Peritia 26 (2015), pp. 47-64.

B. Davis, 'The lunar year of the Coligny calendar as a precedent for the insular lunar year', Talanta 38-39 (2006-7), pp. 9-34.

G.B. De Rossi and L. Duchesne, Acta Sanctorum Novembris 2.1 (Brussels: Bollandists, 1894).

A. Degrassi, Inscriptiones Italiae 13: fasti et elogia, fasciculus 2: Fasti anni Numani et Iuliani, accedunt ferialia, menologia rustica, parapegmata (Rome: Libreria delle Stato, 1963).

A. Dierkens, Abbayes et chapitres entre Sambre et Meuse (VIle-Xle siècles): contribution à I'histoire religieuse des campagnes du Haut Moyen Age (Sigmaringen: Jan Thorbecke, 1985).

A. Dierkens, 'Saint Amand et la foundation de l'abbaye de Nivelles', Revue du Nord 69 (1986), pp. $225-35$

A. Dierkens, 'Prolégomènes à une histoire des relations culturelles entre les îles britanniques et le continent pendant le Haut Moyen Age: la diffusion du monachisme dit colombanien ou iro-franc dans quelques monastères de la région parisienne au $\mathrm{VII}^{\mathrm{e}}$ siècle et la politique religieuse de la reine Bathilde', in H. Atsma (ed.), La Neustrie: les pays au nord de la Loire de 650 à 850, 2 vols (Sigmaringen: Jan Thorbecke, 1989), vol 2, pp. 371-94.

A. Dierkens, 'Notes biographiques sur aint Amand, abbé d'Elnone et éphémère éveque de Maastricht († peu après 676),' in E. Bozoky (ed.), Saints d'Aquitaine: missionaires et pélerins du haut Moyen Âge (Rennes: Presses Universitaires de Rennes, 2010), pp. 63-80.

A. Dierkens, 'Maubeuge et Nivelles à la fin du VII ${ }^{\mathrm{e}}$ siècle: note sur deux passages de la Vita sanctae Aldegundae prima (BHL 244)', in C. Depauw et al. (eds), Hainault: la terre et les hommes (Mons: Hannonia, 2016), pp. 23-47.

J. Divjak and W. Wischmeyer, Das Kalenderbuch von 354: der Chronograph des Filocalus, 2 vols (Wien: Holzhausen, 2014).

I. Dobcheva, 'The umbrella of Carolingian computus', in M.J. Muñoz Jiménez, P. Cañizares Ferriz, and C. Martin (eds), La compilación del saber en la edad media (Porto: Fédération Internationale des Instituts d'Études Médiévales, 2013), pp. 211-30.

B. Englisch, Zeiterfassung und Kalenderprogrammatik in der frühen Karolingerzeit: das Kalendarium der Hs. Köln DB 83-2 und die Synode von Soissons 744 (Stuttgart: Thorbeke, 2002).

M. Esposito, 'On the pseudo-Augustinian treatise, De mirabilibus sanctae scripturae, written in Ireland in the year 655', Proceedings of the Royal Irish Academy 35C (1918-20), pp. 189-207 
A. Fingernagel, Die illuminierten lat. Handschriften deutscher Provenienz der Staatsbibliothek PK Berlin, 8.-12. Jahrhundert (Wiesbaden: Harrassowitz, 1991).

J. Fontaine, Isidore de Séville: Traité de la nature (Bordeaux: Féret et fils, 1960).

H. Frank, 'Die Briefe des heiligen Bonifatius und das von ihm benutzte Sakramentar', in Sankt Bonifatius: Gedenkausgabe zum zwölfhundertsten Todestag (Fulda: Parzeller, 1954), pp. 58-93.

K. Gamber, Das Bonifatius-Sakramentar und weitere frühe Liturgiebücher aus Regensburg (Regensburg: Friedrich Pustet, 1975).

E. Gibbon, The History of the Decline and Fall of the Roman Empire, 6 vols (London, 1776-89, repr. 2005).

L. Gougoud, Christianity in Celtic lands (London: Sheed \& Ward, 1932, repr. Dublin: Institute for Advanced Studies, 1992).

E. Graff, 'The recension of two Sirmond texts: Disputatio Morini and De divisionibus temporum', in I. Warntjes and D. Ó Cróinín (eds), Computus and Its Cultural Context (Turnhout: Brepols, 2010), pp. $112-42$

M. Gretsch, 'Athelthryth of Ely in a lost calendar from Munich', Anglo-Saxon England 35 (2006), pp. 159-77.

C. Grocock and I.N. Wood, Abbots of Wearmouth and Jarrow (Oxford: Clarendon Press, 2013).

P. Grosjean, 'Recherches sur les debuts de la controverse pascale chez les Celtes', Analecta Bollandiana 64 (1946), pp. 200-44.

P.Grosjean, 'Sur quelques exégètes irlandaise du VII' siècle', Sacris Erudiri 7 (1955), pp. 67-98.

P. Grosjean, 'Un fragment d'obituaire Anglo-Saxon du VIII siècle naguère conservé à Munich', Analecta Bollandiana 79 (1961), pp. 320-45.

A. Hänggi and A. Schönherr, Sacramentarium Rhenaugiense: Handschrift Rh 30 der Zentralbibliothek Zürich (Freiburg i. d. Schweiz: Universitätsverlag, 1970).

C.H. Haskins, Studies in the History of Mediaeval Science (Cambridge: Harvard University Press, 1924).

C.H. Haskins, The Renaissance of the Twelfth Century (Cambridge: Harvard University Press, 1927).

A. Hauck, Kirchengeschichte Deutschlands, vol. 1 (3rd and 4th ed., Leipzig: J. C. Hinrichs'sche Buchhandlung, 1904).

G. Henderson, Vision and Image in Early Christian England (Cambridge: Cambridge University Press, 1999).

L. Holford-Strevens, 'Paschal lunar calendars up to Bede', Peritia 20 (2008), 165-208. 
L. Holford-Strevens, 'Marital discord in Northumbria: Lent and Easter, his and hers', in I. Warntjes and D. Ó Cróinín (eds), Computus and Its Cultural Context (Turnhout: Brepols, 2010), pp. 143-58.

L. Holford-Strevens, The Disputatio Chori et Praetextati: The Roman Calendar for Beginners (Turnhout: Brepols, 2019).

L. Holtz, 'Le Parisinus Latinus 7530, synthese cassinienne des arts libéraux', Studi medievali, 3rd series 16 (1975), pp. 97-152.

E. Honée, 'St Willibrord in recent historiography', in P.N. Holtrop and H. McLeod, Missions and missionaries (Woodbridge: Boydell, 2000), pp. 16-31.

C.W. Jones, 'Polemius Silvius, Bede, and the names of the months', Speculum 9 (1934), pp. 50-56.

C.W. Jones, Bedae Pseudepigrapha: Scientific Writings Falsely Attributed to Bede (Ithaca: Cornell University Press, 1939).

C.W. Jones, 'A legend of St. Pachomius', Speculum 18 (1943), pp. 198-210, repr. in W.M. Stevens (ed.), Bede, the Schools and the Computus (Aldershot: Variorum, 1994), article VII.

C.W. Jones, Bedae opera de temporibus (Cambridge: The Medieval Academy of America, 1943).

C. Kendall and F. Wallis, Bede: On the Nature of Things and On times (Liverpool: Liverpool University Press, 2010).

J.F. Kenney, The Sources for the Early History of Ireland: Ecclesiastical (New York: Columbia University Press, 1929, repr. Dublin: Four Courts, 1997).

B. Krusch, Studien zur christlich-mittelalterlichen Chronologie: der 84jährige Ostercyclus und seine Quellen (Leipzig: Veit, 1880).

B. Krusch, 'Die Einführung des griechischen Paschalritus im Abendlande', Neues Archiv der Gesellschaft für ältere deutsche Geschichtskunde 9 (1884), pp. 99-169.

B. Krusch, 'Chronologisches aus Handschriften', Neues Archiv der Gesellschaft für ältere deutsche Geschichtskunde 10 (1885), pp. 81-94.

B. Krusch, 'Das Datum des Concils von Soissons 744 März 3.', Neues Archiv der Gesellschaft für ältere deutsche Geschichtsforschung 30 (1905), pp. 708-9.

B. Krusch, 'Studien zur christlich-mittelalterlichen Chronologie: die Entstehung unserer heutigen Zeitrechnung', Abhandlungen der Preußischen Akademie der Wissenschaften Jahrgang 1937, phil.hist. Klasse 8 (1938).

W. Levison, 'St. Willibrord and his place in history', Durham University Journal 32 (1940), pp. 23-41, repr. in idem, Aus rheinischer und fränkischer Frühzeit: ausgewählte Aufsätze (Düsseldorf: Schwann, 1948), pp. 314-29.

E.A. Loew (later Lowe), Die ältesten Kalendarien aus Monte Cassino (Munich: Beck, 1908). 
M. Mac Carron, 'Bede, Irish computistica and Annus Mundi', Early Medieval Europe 23 (2015), pp. 290-307.

M. Mac Carron, Bede and Time: Computus, Theology and History in the Early Medieval World (London: Routledge, 2019).

G. MacGinty, 'The Irish Augustine: De mirabilibus sacrae scripturae', in P. Ní Chatháin and M. Richter (eds), Ireland und die Christenheit: Bibelstudien und mission (Stuttgart: Klett-Cotta, 1987), pp. 70-83.

D. Mc Carthy, 'Easter principles and a fifth-century lunar cycle used in the British Isles', Journal for the History of Astronomy 24 (1993), pp. 204-24.

P. Meyvaert, 'Discovering the calendar (annalis libellus) attached to Bede's own copy of De temporum ratione', Analecta Bollandiana 120 (2002), pp. 5-64.

T. Mommsen, Corpus Inscriptionum Latinarum, vol. 1 (Berlin, 1863, 2nd ed. 1893).

G. Morin, 'Les quatre plus anciens calendriers du Monte-Cassin (VIII $-\mathrm{IX} \mathrm{X}^{\mathrm{e}}$ siècles)', Revue Bénédictine 25 (1908), pp. 486-97.

A.A. Mosshammer, Easter Computus and the Origins of the Christian Era (Oxford: Oxford University Press, 2008).

C.P.E. Nothaft, Walcher of Malvern: De lunationibus and De dracone (Turnhout: Brepols, 2017).

C.P.E. Nothaft, Scandalous Error: Calendar Reform and Calendrical Astronomy in Medieval Europe (Oxford: Oxford University Press, 2018).

D. Ó Corráin, Clavis litterarum Hibernensium: Medieval Irish Books and Texts (c.400-c.1600)

(Turnhout: Brepols, 2017).

D. Ó Cróinín, 'The Irish provenance of Bede's computus', Peritia 2 (1983), pp. 229-47, repr. in idem, Early Irish History, pp. 173-90.

D. Ó Cróinín, 'Rath Melsigi, Willibrord, and the earliest Echternach manuscripts', Peritia 3 (1984), pp. 17-49, repr. in idem, Early Irish History, pp. 145-72 (with an appendix by T. Fanning).

D. Ó Cróinín, 'Merovingian politics and insular calligraphy: the historical background to the Book of Durrow and related manuscripts', in M. Ryan (ed.), Ireland and Insular Art, A.D. 500-1200 (Dublin: Royal Irish Academy, 1987), pp. 40-43.

D. Ó Cróinín, 'Bischoff's Wendepunkte fifty years on', Revue Bénédictine 110 (2000), pp. 204-37.

D. Ó Cróinín, 'Bede’s Irish computus', in idem, Early Irish History, pp. 201-12.

D. Ó Cróinín, Early Irish History and Chronology (Dublin: Four Courts, 2003).

P. Ó Riain, 'Les Vies de saint Fursy: les sources irlandaises', Revue du nord 68 (1986), pp. 405-13.

P. Ó Riain, Feastdays of the Saints: A History of Irish Martyrologies (Bruxelles: Société des Bollandistes, 2006). 
P. Ó Riain, A Dictionary of Irish Saints (Dublin: Four Courts, 2011).

M. Ohashi, The Impact of the Paschal Controversy: Computus, Exegesis and Church History in Early Britain and Ireland (unpublished Ph.D. thesis, Nagoya, 1999).

J.T. Palmer, 'Computus after the paschal controversy of AD 740', in I. Warntjes and D. Ó Cróinín (eds), The Easter Controversy of Late Antiquity and the Early Middle Ages: Its Manuscripts, Texts, and Tables (Turnhout: Brepols, 2011), pp. 213-41.

J.T. Palmer, 'Calculating time and the end of time in the Carolingian world, c. 740-820', English Historical Review 126 (2011), pp. 1307-31.

J.-M. Picard, 'Church and politics in the seventh century: the Irish exile of King Dagobert II', in idem (ed.), Ireland and Northern France, AD 600-850 (Dublin: Four Courts, 1991), pp. 27-52.

F. Piper, Karls des Grossen Kalendarium und Ostertafel (Berlin: Decker, 1858).

H. Pirenne, Mahomet et Charlemagne (Paris, 1937).

C. Plummer, Baedae opera historica, 2 vols (Oxford: Oxford University Press, 1896).

W. Pohl, 'The transformation of the Roman world revisited', in J. Kreiner and H. Reimitz (eds), Motions of Late Antiquity: essays on religion, politics, and society in honour of Peter Brown (Turnhout: Brepols, 2016), pp. 45-61.

F. Prinz, Frühes Mönchtum im Frankenreich (2nd ed., Darmstadt: Wissenschaftlich Buchgesellschaft, 1988).

O. Rackham, Transitus beati Fursei: a translation of the $8^{\text {th }}$ century manuscript Life of Saint Fursey (Norwich: Fursey Pilgrims, 2001, repr. 2007).

P. Riché, Les écoles et l'enseignement dans l'Occident chrétien: de la fin du V' siècle au milieu du XI siècle (Paris: Aubier Montaigne, 1979).

P. Salmon, 'Le martyrologe-calendrier conserve dans le manuscript latin 14086 de Paris et ses origins', Revue Bénédictine 56 (1945-6), pp. 42-57.

M.R. Salzmann, On Roman Time: The Codex-calendar of 354 and the Rhythms of Urban Life in Late Antiquity (Berkeley: University of California Press, 1990).

J. Schmid, Die Osterfestberechnung auf den britischen Inseln vom Anfang des vierten bis zum Ende des achten Jahrhunderts (Regensburg: Verlagsanstalt, 1904).

M. Schneiders, 'The Irish calendar in the Karlsruhe Bede (Karlsruhe, Badische Landesbibliothek, Cod. Aug. CLXVII, ff. 16v-17v)', Archiv für Liturgiewissenschaft 31 (1989), pp. 33-78.

H. Schüling, 'Die Handbibliothek des Bonifatius', Archiv für Geschichte des Buchwesens 4 (1961-3), pp. 286-349. 
E. Schwartz, 'Christliche und jüdische Ostertafeln', Abhandlungen der königlichen Gesellschaft der Wissenschaften zu Göttingen, philologisch-historische Klasse, Band 8, Nr. 6 (Berlin: Weidmannsche Buchhandlung, 1905).

T. Sickel, 'Die Lunarbuchstaben in den Kalendarien des Mittelalters', Sitzungsberichte der Akademie der Wissenschaften in Wien, phil.-hist. Klasse, 38 (1862), pp. 153-201.

P. Siffrin, 'Das Walderdorffer Kalenderfragment saec. VIII und die Blätter eines Sakramentars aus Regensburg', Ephemerides Liturgicae 47 (1933), pp. 201-24.

M. Smyth, 'Once in four: the leap year in early medieval thought', in I. Warntjes and D. Ó Cróinín (eds), Late Antique Calendrical Thought and Its Reception in the early Middle Ages (Turnhout: Brepols, 2017), pp. 229-64.

K. Springsfeld, 'Eine Beschreibung der Handschrift St. Gallen, Stiftsbibliothek, 225', in I. Warntjes and D. Ó Cróinín (eds), Computus and Its Cultural Context in the Latin West, AD 300-1200 (Turnhout: Brepols, 2010), pp. 204-37.

S. Stern, Calendars in Antiquity: Empires, States, and Societies (Oxford: Oxford University Press, 2012).

A. Strobel, Texte zur Geschichte des frühchristlichen Osterkalenders (Münster: Aschendorffsche Velragsbuchhandlung, 1984).

A. van Berkum, 'Willibrord en Wilfrid: een oderzoek naar hun wederzijdse betrekkingen,' Sacris Erudiri 23 (1978), pp. 347-417.

G.S.M. Walker, Sancti Columbani Opera (Dublin: Dublin Institute for Advanced Studies, repr. 1997).

J.M. Wallace-Hadrill, 'Rome and the early English church: some questions of transmission', in La chiese nei regni dell'Europa occidentale e i loro rapport con Roma sino all'800 (Spoleto: Centro italiano di studi sull'alto medioevo, 1960), pp. 519-48 (article), pp. 575-82 (discussion).

M. Walsh and D. Ó Cróinín, Cummian's Letter De controversia paschali and the De ratione conputandi (Toronto: Pontifical Institute of Mediaeval Studies, 1988).

C. Wampach, Geschichte der Grundherrschaft Echternach im Frühmittelalter, 2 vols (Luxemburg: Luxemburger Kunstdruckerei, 1929-30).

I. Warntjes, 'The Munich Computus and the 84 (14)-year Easter reckoning', Proceedings of the Royal Irish Academy 107C (2007), pp. 31-85.

I. Warntjes, Munich Computus: Text and Translation. Irish Computistics between Isidore of Seville and the Venerable Bede and Its Reception in Carolingian Times (Stuttgart: Franz Steiner Verlag, 2010).

I. Warntjes, 'The Computus Cottonianus of AD 689: a computistical formulary written for Willibrord's Frisian mission', in I. Warntjes and D. Ó Cróinín (eds), The Easter Controversy of Late Antiquity and the Early Middle Ages: Its Manuscripts, Texts, and Tables (Turnhout: Brepols, 2011), pp. 173-212.

I. Warntjes, 'Irische Komputistik zwischen Isidor von Sevilla und Beda Venerabilis: Ursprung, karolingische Rezeption und Forschungsperspektiven', Viator 42 Multilingual (2011), pp. 1-31. 
I. Warntjes, 'Köln als naturwissenschaftliches Zentrum in der Karolingerzeit: die frühmittelalterliche Kölner Schule und der Beginn der fränkischen Komputistik', in H. Finger and H. Horst (eds), Mittelalterliche Handschriften der Kölner Dombibliothek, Viertes Symposion (Köln: Erzbischöfliche Diözesan- und Dombibliothek, 2012), pp. 41-96.

I. Warntjes, 'Seventh-century Ireland: the cradle of medieval science?', in M. Kelly and C. Doherty (eds), Music and the Stars: Mathematics in Medieval Ireland (Dublin: Four Courts, 2013), pp. 44-72.

I. Warntjes, 'An Irish eclipse prediction of AD 754: the earliest in the Latin West', Peritia 24-25 (201314), pp. 108-115.

I. Warntjes, 'Victorius vs Dionysius: the Irish Easter controversy of AD 689,' in P. Moran and I. Warntjes (eds), Early Medieval Ireland and Europe: Chronology, Contacts, Scholarship (Turnhout: Brepols, 2015), pp. 33-97.

I. Warntjes, 'Computus as scientific thought in Ireland and the early medieval West', in R. Flechner and S. Meeder (eds), The Irish in Early Medieval Europe: Identity, Culture and Religion (New York: Macmillan, 2016), pp. 158-78.

I. Warntjes, 'The continuation of the Alexandrian Easter table in seventh-century Iberia and its transmission to ninth-century Francia (Isidore, Etymologiae 6.17)', Revue d'histoire des textes n.s. 13 (2018), pp. 185-94.

I. Warntjes and D. Ó Cróinín (eds), Computus and Its Cultural Context in the Latin West, AD 300-1200 (Turnhout: Brepols, 2010).

I. Warntjes and D. Ó Cróinín (eds), The Easter Controversy of Late Antiquity and the Early Middle Ages: Its Manuscripts, Texts, and Tables (Turnhout: Brepols, 2011).

L.T. White (ed.), The Transformation of the Roman World: Gibbon's Problem after Two Centuries (Berkley: University of California Press, 1966).

C. Wickham, The Inheritance of Rome: A History of Europe from 400 to 1000 (London: Allan Lane, 2009).

H.A. Wilson, The Calendar of St. Willibrord (Woodbridge: Henry Bradshaw Society, 1918).

I.N. Wood, The Transformation of the Roman West (Leeds: Arc Humanities Press, 2018).

V. Yarza Urquiola and F.J. Andrés Santos, Isidoro de Sevilla, Etimologías, Libro V: De legibus - De temporibus (Paris: Les belles lettres, 2013)

M. Ziegler, 'The Ripon connection? Willibrord, Wilfrid, and the mission to Frisia', The Heroic Age 6 (2003).

H. Zimmer, 'Keltische Kirche in Britannien und Irland', Realencyklopädie für protestantische Theologie und Kirche, $3^{\text {rd }}$ ed., vol. 10 (1901), pp. 204-43, trans. by A. Meyer as The Celtic Church in Britain and Ireland (London: David Nutt, 1902). 